\title{
The Nature of the Intertidal Zonation of Plants and Animals.
}

By

\author{
John Colman, B.A., \\ From the Plymouth Laboratory and Harvard University.
}

With 15 Figures in the Text.

WhiLe Student-Probationer at the Plymouth Laboratory, I started a quantitative examination of the faunas associated with seaweeds, an essential preliminary to which was some knowledge of the limits of distribution of the seaweeds in relation to tidal levels. Such limits, as observed in Wembury Bay, together with those of the commoner gastropods and cirripedes, are described in this paper.

Wembury Bay is very fairly sheltered from all winds except those from between S.S.W. and S.E., the weight of sou'westerly gales being taken by the Great Mewstone (see Map, Fig. 1). Most of the bay is less than five fathoms deep at low water, and the high rocks at the seaward end of the reef protect the slightly lower middle and landward portions on which this work was done. The high, seaward rocks are in many places completely bare of algæ above the Laminaria digitata zone, being thickly covered instead by the barnacles Chthamalus stellatus and Balanus balanoides. That a strong southerly gale can work considerable destruction in Wembury Bay was shown on December 4th, 1929, when a belt of Laminarias was thrown up above high water mark some two hundred yards long, thirty yards wide and with a steep seaward face six feet high, all firmly pounded together, and consisting of whole plants, often with the holdfasts still attached to rocks up to twenty pounds in weight. Wembury Bay probably suffers from a minimum of pollution as the area draining into it is but sparsely inhabited, and the River Yealm brings down very little fresh water, being really an arm of the sea like Salcombe Harbour farther east.

Church Reef or Ledge, also called Blackstone Reef or Ledge, projects about a quarter of a mile into Wembury Bay, two miles east of Plymouth Sound, and is entirely covered at high water of spring tides. It was selected on the grounds of accessibility and richness of algal growth after the whole coastline had been examined from Bolt Tail to Looe.

NEW SERIES.-VOL. XVIII. NO. 2. JANUARY, 1933. 
First of all, a rock (hereafter called Central Rock or C.R.) was chosen about the middle of the reef, and from it three traverses were marked out by triangular holes cut in the rocks at intervals of about forty-five feet. Traverse A, 222.5 feet, lay towards the Coastguard lookout on Gara Head; Traverse B, 367.5 feet, towards the Great Mewstone; Traverse C, 382 feet, towards Wembury Church. In addition, Traverse D was laid out from the landward end of Traverse C for 198 feet in an easterly direction. $\mathrm{A}$ and $\mathrm{B}$ reached low water mark on the east and west

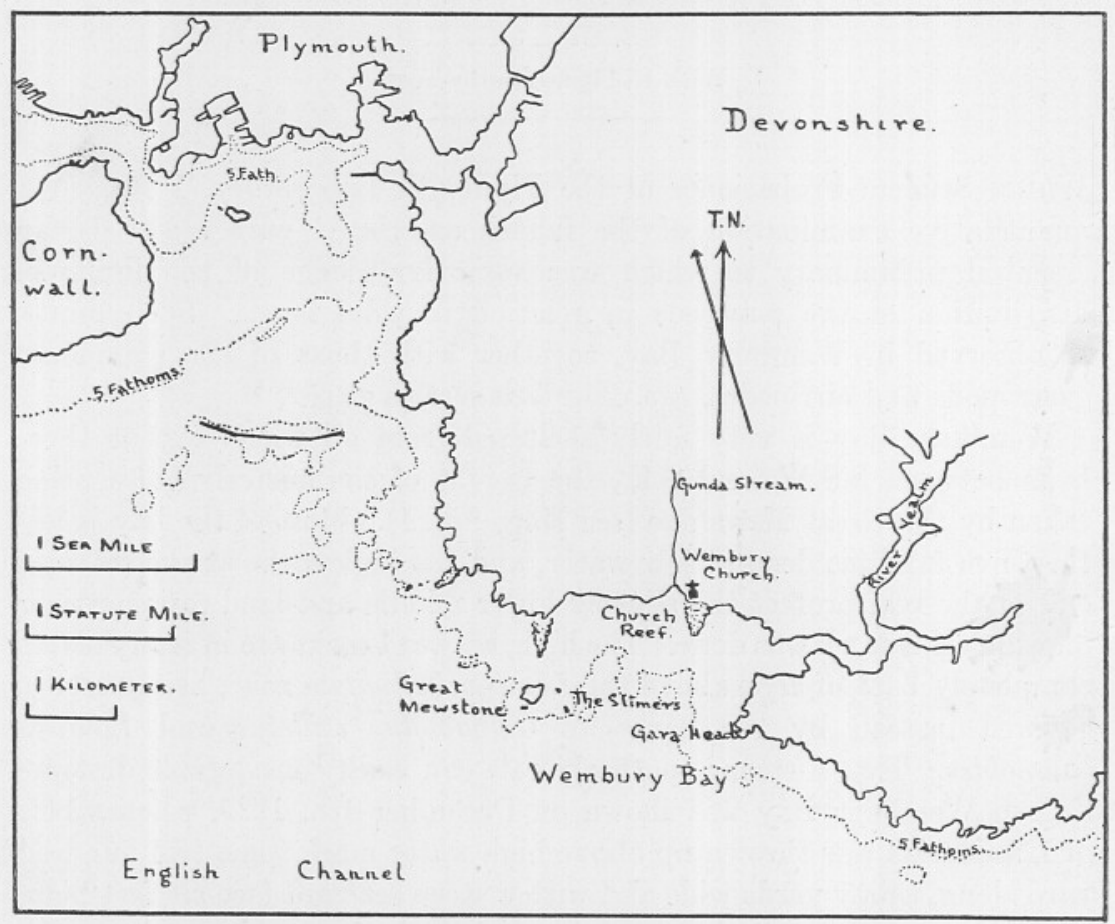

FIG. 1.-Map showing the position of Church Reef in the Plymouth District.

sides respectively of the reef, $\mathrm{C}$ was almost all between high and low water neaps, and D went above the limits of marine algal vegetation. Table I gives the details of the traverses.

Their approximate positions are shown in the Map, Fig. 2, which is taken from Devonshire Sheet CXXX 6 of the 1/2500 Ordnance Survey. The position of Central Rock was obtained by a compass fix, and cannot therefore be taken as more than approximately correct.

Each traverse was examined throughout in detail with regard to the common plants and animals living on the rock, and was then levelled to 
the nearest hundredth of a foot, using a Casella level. This work was done by Mr. Michael Spender, to whom I am deeply grateful.

\section{TABLE I.}

\section{Dimensions and True Bearings of Traverses.}

True Bearing.

Central Rock to Mark I, in feet

C VII to D I, in feet

I to II

II to III

III to IV

IV to $\mathrm{V}$

$\mathrm{V}$ to $\mathrm{VI}$

VI to VII

VIII onwards

Total

$\begin{array}{cccc}\text { A. } & \text { B. } & \text { C. } & \text { D. } \\ 159^{\circ} & 245^{\circ} & 4^{\circ} & 94^{\circ} \\ 50 & 43 \cdot 5 & 65 & - \\ - & - & - & 60 \\ 52 & 44 & 41 & 61 \\ 39 \cdot 5 & 41 & 42 & 57 \\ 35 & 41 & 44 & 20 \\ 46 & 74 & 67 & - \\ - & 35 & 64 & - \\ - & 30 & 59 & - \\ - & 59 & - & - \\ 222 \cdot 5 & 367 \cdot 5 & 382 & 198\end{array}$

The starting-point for this levelling was a bench-mark, 20.56 feet above Ordnance Datum, on the S.W. corner of the house adjoining Wembury Mill, and $2 \cdot 70$ feet from the ground, and all level traverses were of course checked back to the bench-mark. All the marks on the traverses and where possible all intermediate points were levelled with the foot of the staff resting on solid rock.

\section{TABLE II.}

Tidal Data for Devonport, 1930.

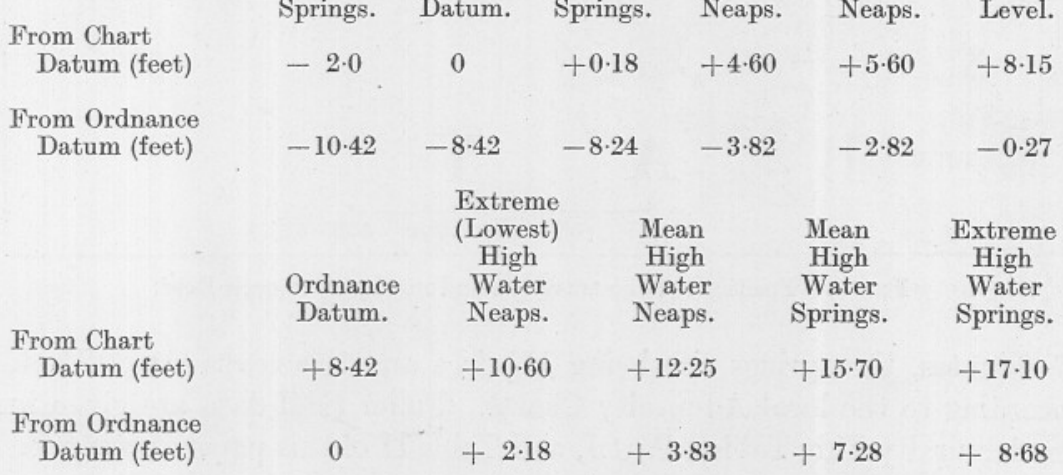


The nearest place for which accurate tidal data are available is Devonport, distant some five miles by sea, where High Water at Full Moon and Change of Moon (High Water Interval) occurs at V hours

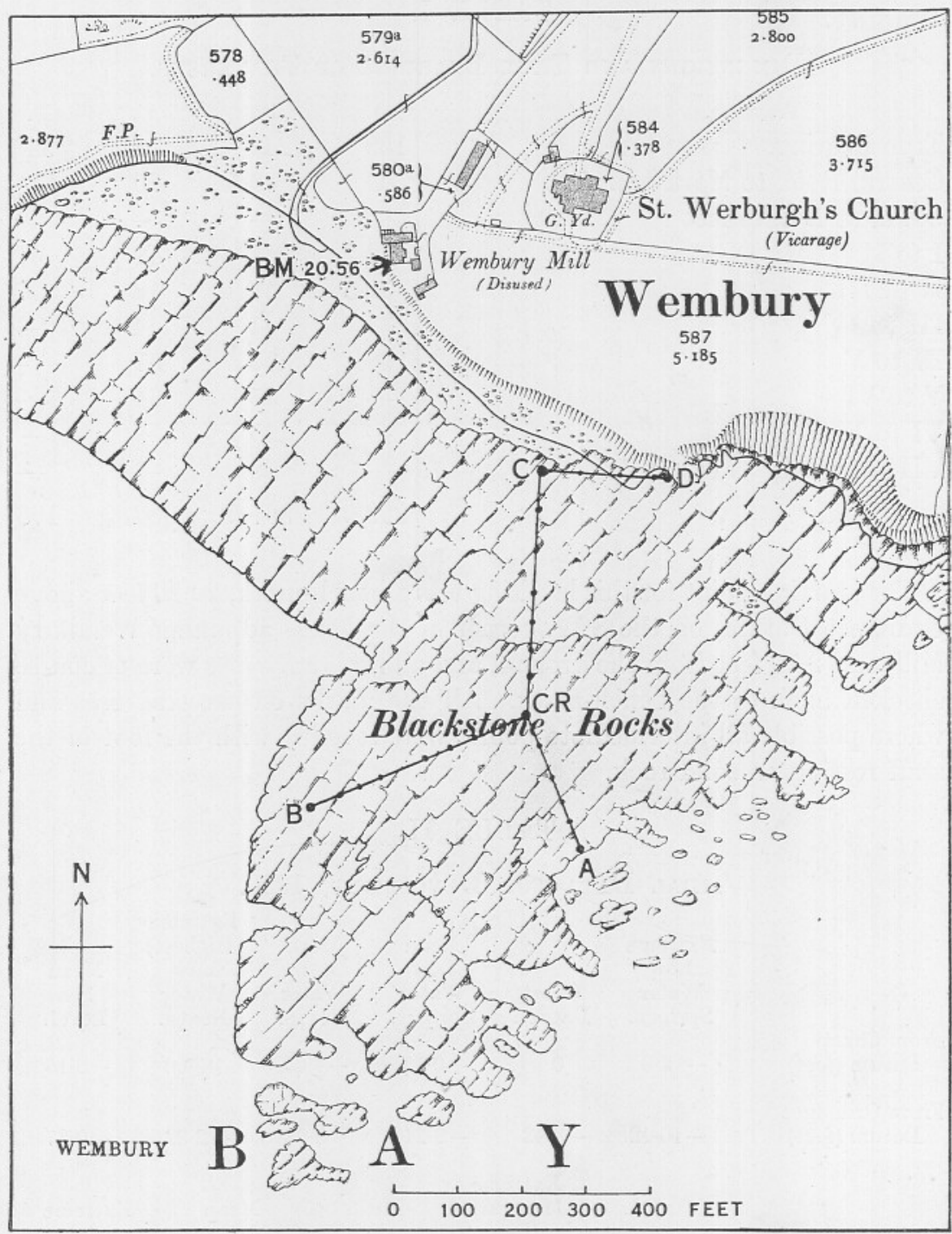

Fig. 2.-Positions of the traverses and marks on Church Reef.

37 minutes, the springs rise being $15 \frac{1}{2}$ feet and the neaps rise 12 feet, according to the local Admiralty Charts. Fuller tidal data are given in the Admiralty Tide Tables, Part I, and Table II of this paper is compiled 
from the tide tables forecast for Devonport during the year 1930 and from Table VII on page 382 of the same volume. The datum for tide tables and charts is Low Water of Ordinary Spring Tides; Ordnance Datum is the assumed mean level of the sea at Liverpool, which is 8.42 feet above Chart Datum at Devonport.

From this table it will be seen that the extreme range of the tide at Devonport during 1930 was $19 \cdot 10$ feet. This did not occur on one tide, since the highest high water is not usually preceded or followed by the lowest low water, but rises of 17 or 18 feet are not uncommon at the equinoxes. The mean springs range is $15 \cdot 32$ feet, the mean neaps range 7.65 feet, while at some neap tides there may be as small a rise as 5 feet.

There are no accurate tidal observations for Wembury Bay, so in order to find out whether it was justifiable to use the Devonport data I wrote to the Hydrographic Department of the Admiralty, and received in answer a letter from Admiral Douglas, Hydrographer, saying : “. . . Comparison of the tides at Salcombe, the nearest place east of Devonport at which comparatively full observations have been obtained, with those at Devonport, however, shows a decrease in range of about $6 \%$; and it is therefore probable that a very small decrease also occurs between Devonport and Wembury Bay." If this decrease is in proportion to the distance from Devonport it will not be much more than $1 \%$ at Wembury, or about $0 \cdot 2$ foot at springs, and of course still less at neaps. I have therefore considered the Devonport Data to be applicable in Wembury Bay. In this connection it was observed that frequently the low water level on Church Reef was a few inches above that predicted for Devonport, but on several occasions it went a few inches below. In calm weather I never noticed a discrepancy of as much as half a foot. It is also, perhaps, worth mentioning that anyone in Wembury Bay can tell the level of the sea at any time within a couple of hours of low water by observing the relative heights of the Inner and Outer Slimers, two groups of rocks east of the Great Mewstone. The Inner Slimers reach 10 feet above Chart Datum, the Outer Slimers only four. In calm weather the sea level could be estimated with confidence to the nearest foot.

Some excuse must be offered for not employing the metric system. The reason is that some of the tidal data, ordnance datum and the levelling of the traverses are, or purport to be, accurate to $1 / 100$ foot. This is approximately $3 \mathrm{~mm}$., which being more than one millimetre and less than one centimetre cannot be represented with equal accuracy on a metric scale. A conversion table is given in Table III.

The plants whose ranges were examined were only the largest and commonest on the reef, this work being originally supplementary to a quantitative estimate of their associated faunas. The animals in this 
paper are all common and obvious, no attempt having been made to investigate rarities.

TABLE III.

\begin{tabular}{cccc}
\multicolumn{2}{c}{ Conversion Table For Feet } & into & Metres, \\
Feet. & Metres. & Feet. & Metres. \\
$0 \cdot 1$ & $0 \cdot 03$ & 7 & $2 \cdot 13$ \\
$0 \cdot 2$ & $0 \cdot 06$ & 8 & $2 \cdot 44$ \\
$0 \cdot 3$. & $0 \cdot 09$ & 9 & $2 \cdot 74$ \\
$0 \cdot 4$ & $0 \cdot 12$ & 10 & $3 \cdot 05$ \\
$0 \cdot 5$ & $0 \cdot 15$ & 11 & $3 \cdot 35$ \\
$0 \cdot 6$ & $0 \cdot 18$ & 12 & $3 \cdot 66$ \\
$0 \cdot 7$ & $0 \cdot 21$ & 13 & $3 \cdot 96$ \\
$0 \cdot 8$ & $0 \cdot 24$ & 14 & $4 \cdot 27$ \\
$0 \cdot 9$ & $0 \cdot 27$ & 15 & $4 \cdot 57$ \\
1 & $0 \cdot 30$ & 16 & $4 \cdot 88$ \\
2 & $0 \cdot 61$ & 17 & $5 \cdot 18$ \\
3 & $0 \cdot 91$ & 18 & $5 \cdot 49$ \\
4 & $1 \cdot 22$ & 19 & $5 \cdot 79$ \\
5 & $1 \cdot 52$ & 20 & $6 \cdot 10$ \\
6 & $1 \cdot 83$ & &
\end{tabular}

The following plants and animals had their limits of distribution accurately worked out on Church Reef :-

ALGÆ.

FLORIDEA.

*Polysiphonia lanosa (L.) =P. fastigiata (auct).

Chondrus crispus Stackhouse.

Gigartina stellata Stackhouse.

PHЖOPHYCEÆ.

Pelvetia canaliculata (L.).

Fucus spiralis (L.).

Fucus serratus (L.).

*Ascophyllum nodosum (Le Jol).

Laminaria digitata (Lamouroux).

LICHENS.

Lichina pygmaca (Ag.).

\section{MOLLUSCA.}

GASTROPODA.

Littorina neritoides (L.).

Littorina saxatilis (Olivi)=rudis (Maton).

Littorina obtusata (L.) =littoralis (L.).

* A. nodosum and $P$. lanosa are in this paper treated as a unit, since on the four traverses wherever Ascophyllum was found, there also was Polysiphonia lanosa growing upon it. 
Eittorina littorea (L.).

Ositinus lineatus (da Costa) (=Monodonta crassa).

Gibbula umbilicatis (da Costa).

Gibbula cineraria (L.).

Calliostoma zizyphinum (L.).

Nucella (Purpura) lapillus (L.).

Patella vulgata (L.).

\section{CRUSTACEA.}

\section{CIRRIPEDIA.}

Chthamalus stellatus (Poli).

Balanus balanoides (L.).

Balanus perforatus (Bruguière).

Verruca stroemia (O. F. Müller).

Identifications of the algæ were confirmed by Mr. Geoffrey Tandy of the British Museum (Nat. Hist.). The names are as given in Batters' (1902) Catalogue of the British Marine Algæ, with the exception of Polysiphonia lanosa (L.), which is more familiar as P. fastigiata. Tandy (1931) has shown that the latter name is indefensible.

For the identifications of the animals I am myself responsible. The names do not vary from those in the Plymouth Marine Fauna (Marine Biological Association, 1931) with the exceptions of Littorina saxatilis and $L$. obtusata. The necessity for these alterations is given by Dautzenburg and Fischer (1912) and by Colman (1932). I am very grateful for the help in this matter of members of the staff of the Plymouth Laboratory, in particular Messrs. G. A. Steven and J. E. Smith.

\section{Detailed Description of Traverses.}

Traverse A. $222 \cdot 5$ feet. From Central Rock S.E. towards Gara Head. See Fig. 3.

Central Rock (C.R.), at the top of which this traverse starts, is a roughly pyramidal eminence of grit, about 10.5 feet high on the seaward side, where it is separated from the southern portion of the reef by a cleft about four feet wide whose floor is just above Mean Low Water Neaps. The upper half is largely covered with the lichen Lichina pygmaa, particularly on seaward or southward-facing slopes, which are exposed to the greatest amounts of both sun and surf, and the surface of the whole mass of rock is patchily covered with barnacles. Small Patella vulgata are fairly common as high as C.R. On Traverse A, Lichina pygmaea is growing thickly at C.R., 6.04 feet above Ordnance Datum (O.D.) and one foot below Mean High Water Springs, and reaches its lower limit at four 
places, namely 12 feet, 18 feet, 28 feet, and 38 feet from C.R., whose heights above O.D. are 0.4 feet, 0.4 feet, 0.57 feet, and 0.3 feet respectively.* (Heights are given relative to Ordnance Datum, since this level is constant throughout Great Britain. Chart Datum varies from place to place according to the amplitude of the tide.) The barnacles at C.R. belong exclusively to Chthamalus stellatus, which on Traverse A extends as far as 52 feet, at the foot of Central Rock, 4.44 feet below 0.D. Balanus balanoides is also common on the lower parts of the rock, the upper limit on this traverse being at 7.5 feet, +2.5 feet. Occasional stunted plants of Fucus spiralis were growing between +3 feet and +5 feet, but too rarely to allow their precise limits to be determined. Littorina saxatilis is common on the upper parts of Central Rock, but its lower limit was not ascertained on this traverse.

After Central Rock the cleft, mentioned above, is crossed diagonally, and is paved with stones and small boulders, which are bare of algæ, excepting a little Enteromorpha sp. during the summer. The traverse emerges from it up a cliff 2 feet high and overhanging 1 foot, on which are Balanus perforatus in fair numbers and Nucella lapillus, between $-4 \cdot 45$ feet and $-2 \cdot 36$ feet.

From here onwards the traverse, while undulating, gradually descends. For 15 feet the rock is bare of algæ, but supports Nucella lapillus and Balanus balanoides, with Gibbula umbilicalis and Patella from 68 feet to 74 feet, between -1.53 feet and -3.0 feet. From 75 feet to 83.5 feet a belt of scattered Ascophyllum nodosum and Polysiphonia lanosa is crossed. This traverse does not cross the highest Ascophyllum in the vicinity, but the lower limit is very definite at 83.5 feet, 4.05 feet below 0.D. After this point Fucus serratus is the dominant alga, growing thickly almost everywhere. It starts at 89 feet, at -4.05 feet (though it reaches several feet higher on other traverses), and extends down with only occasional gaps to 217.5 feet, 5 feet short of $\mathrm{Av}$, the end of the traverse. On April 2nd, 1931, low water was about 2.5 feet below A v, and this just corresponded with the lower limit of Fucus serratus, 9 feet below O.D. to the nearest half foot. Laminaria digitata first appears in the pool between 116 feet and 121 feet, and occurs where the rock dries out at 130 feet, $6 \cdot 39$ feet below O.D. The next exposed Laminaria is at 161.5 (-6.51 feet). From 177 feet onwards the rock is largely covered by Laminaria digitata and Fucus serratus, further upper limits of the former being at 176 feet ( -6.50 feet), 179 feet $(-6.41$ feet), $200 \cdot 5$ feet $(-6.41$ feet), and 206 feet $(-6 \cdot 7$ feet).

Chondrus crispus first appears between 110 feet and 112.5 feet, the highest point being -5.55 feet, and Gigartina stellata between 104 feet

* Heights are given to the nearest hundredth of a foot if they are where a level reading was taken. Intermediate points are given to the nearest tenth of a foot. 


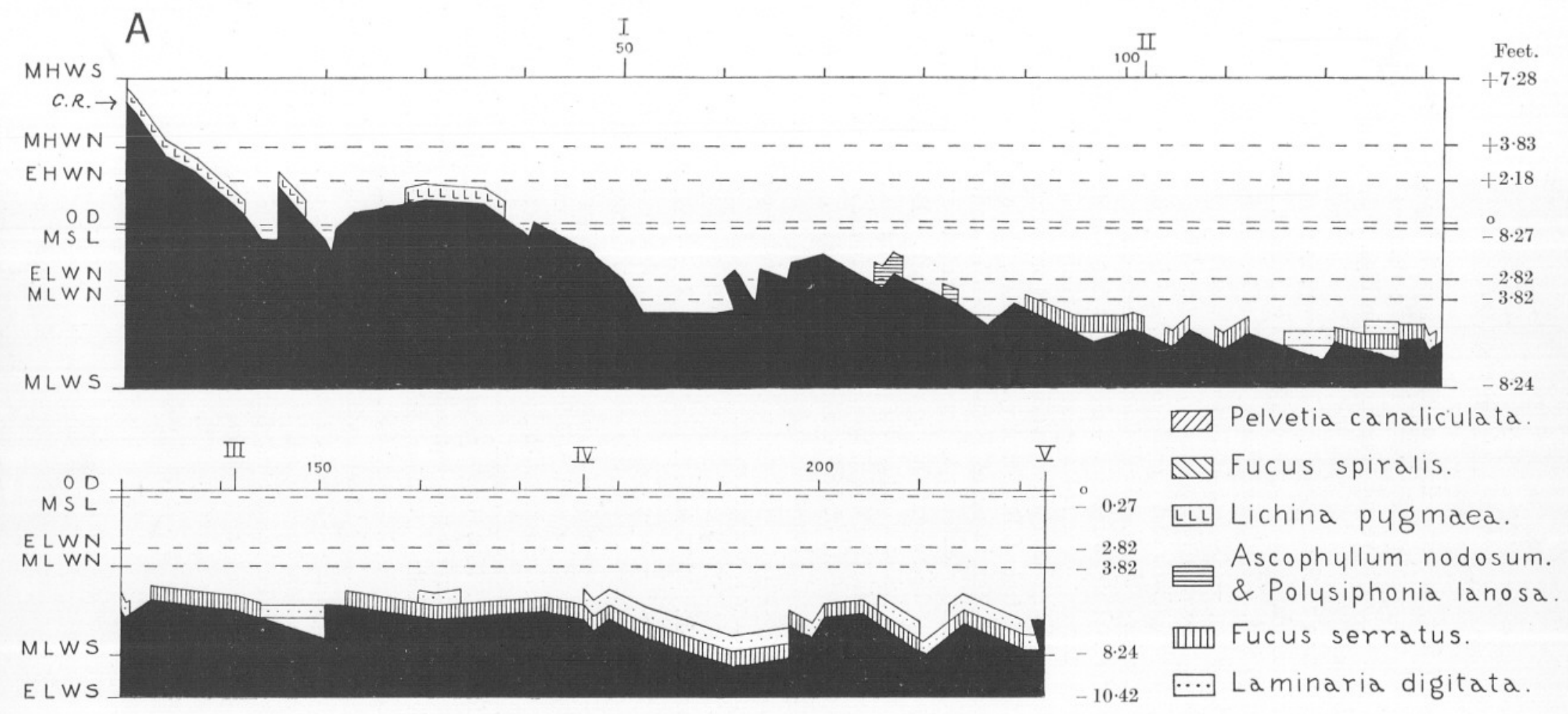

FrG. 3.-Traverse A ; distribution of Lichina pygmaa, Polysiphonia lanosa and fucoid algæ. (Vertical scale twice the horizontal.) 
and 107 feet, its upper limit on this traverse being $-5 \cdot 29$ feet. Henceforward they both occur with increasing richness to the end of the traverse. They have not been included in Figs. 2, 3, 4, and 5 for fear of confusion.

To return to the animals on the traverse, from 61 feet to 75 feet the rock is undulating and supports Balanus balanoides, Nucella lapillus, and, from 68 feet, Gibbula umbilicalis and Patella, the highest point on this stretch being -1.53 feet at 70 feet. The subsequent Ascophyllum belt contains Littorina littorea and $L$. obtusata. These two, together with Gibbula umbilicalis and Nucella lapillus, are fairly common down to the upper limits of Laminaria digitata, but there die out rather suddenly at -6.5 feet. Patella reaches -6.5 feet at 200.5 feet. Gibbula cineraria on this traverse does not appear out of pools until this height, but is common throughout the Laminarian zone at any rate down to -8.78 feet at 191.5 feet from C.R. At A v, -6.48 feet, there is again a covering of barnacles, consisting of Balanus balanoides and B. perforatus. Of these the former extends to between one and two feet below $\mathrm{A} \mathrm{v}$ and $B$. perforatus below extreme low water mark. Below A v there are occasional individuals of Verruca stromia growing on the rock, becoming more common further down, but as they were found in considerable numbers on all holdfasts of Laminaria digitata, I have considered the upper distribution of the barnacle to coincide with that of the alga. Calliostoma zizyphinum occurs at 174 feet $(-6 \cdot 2$ feet) and fairly often from that point down to below low water mark.

Traverse B. $367 \cdot 5$ feet. From Central Rock S.W. towards the Great Mewstone. See Fig. 4.

The first section of this traverse, down to the seaward face of Central Rock, is somewhat similar to the corresponding part of Traverse A, the cleft being crossed between 47.5 feet and 49.5 feet. Again the upper part only of the rock is clothed with Lichina pygmaea extending down to $+0 \cdot 68$ feet, 16 feet from C.R., with occasional stunted Fucus spiralis between +3 feet and +5 feet. Chthamalus stellatus is abundant right down to the cleft, and is again the only barnacle in the upper region where it is accompanied by Patella; Balanus balanoides appears on the slope below 40 feet at a height of $+0 \cdot 29$ feet. Littorina saxatilis is very common at C.R. $(+6.04$ feet) and reaches $9 \cdot 5$ feet $(+2 \cdot 89$ feet $)$, while $L$. obtusata reaches as high as +0.5 feet, 22 feet from C.R. On other traverses these molluses are sometimes found to overlap. Gibbula umbilicalis did not occur in the open hereabouts, but was found in the pools between 16.5 feet and 21.5 feet, and between 27 feet and 36 feet. Each pool also contained Fucus serratus and the second one Laminaria digitata as well, the water levels in the two pools being +0.77 feet and -0.62 feet 
respectively. These pools are both fully exposed to the sun, and only the lower one contained Laminaria. A small pool on Traverse C, however, which is higher than either of them, is sheltered from the sun and contains Laminaria. The lower part of the slope down to the cleft is covered with Fucus serratus and Ascophyllum nodosum from 44 feet to $47 \cdot 5$ feet $(-1 \cdot 27$ feet to $-3 \cdot 16$ feet), and on the cliff out of the cleft Balanus perforatus is fairly common $(-3 \cdot 16$ to $-1 \cdot 40$ feet).

From the top of this cliff until 120 feet, except in pools, the rock is more or less thickly covered with Ascophyllum nodosum and Polysiphonia lanosa, but at 120 feet they stop suddenly 3.7 feet below O.D., having reached $-4 \cdot 11$ feet at 114 feet from C.R. This is one of the clearest zone edges on the reef, and is very obvious to anyone looking up the slope from a seaward direction. There is no grading off; the Ascophyllum is dense right down to its lower limit and is there sharply cut off. Fucus serratus is scattered in this portion of the Ascophyllum zone, below which it becomes the dominant alga, covering nearly all the exposed rock for the rest of the traverse, except for a section near the end, between 337 feet and 364 feet, which is below its lower limit. After the last Ascophyllum at 120 feet, the traverse slopes gently down, generally covered with Fucus serratus but with occasional bare patches, on which Patella are abundant at $-4 \cdot 2$ feet, until at 183.5 feet it enters the largest rock pool on the reef, whose surface was at -6.47 feet on the day it was levelled; this was the lowest to which it sank during low water springs. The pond contains a rich growth of algæ dominated by Laminaria digitata, L. saccharina and Fucus serratus, and is carpeted with Corallines. At 226 feet a rock projecting from the surface is covered with Fucus serratus but no Laminaria.

From the end of this pond the traverse rises steeply 2 feet, and then continues gently downward, thickly covered with Fucus serratus except for a small bare patch on top of a rock at 278 feet (Mark VI). At $275 \cdot 0$ feet the traverse just touches the upper edge of the Laminaria digitata zone, at -6.23 feet. From 280 feet to 294.5 feet a pool is crossed, 1 foot deep, almost choked with Laminaria and carpeted with Corallines, the water level being -6.73 feet. After rising fairly steeply from this pool the traverse again undulates gently downward, still covered with Fucus serratus, except for another bare rock top at 308.5 feet (Mark VII). In two depressions Laminaria digitata appears, at 307 feet ( -6.54 feet) and at 323.5 feet $(-6.51$ feet). From 332.5 feet the downward slope becomes steep; Laminaria digitata is thick from -7.01 feet down, and Fucus serratus dies out at -8.4 feet. Then, after 20 feet at just above extreme low water springs ( $\mathrm{I}$ only saw this part dry out once) and reaching $-10 \cdot 10$ feet at 359.5 feet, the traverse slopes up to its end at 367.5 feet, Fucus serratus reappearing at 362.5 feet at a height of $-8 \cdot 6$ feet. 
Chondrus crispus occurred from 167 feet to $169 \cdot 5$ feet $(-5 \cdot 98$ feet to -5.33 feet) and was present from 243.5 feet to 263 feet except where the rocks were above -4.5 feet, and on the short slope down at 279 feet at -5.5 feet. Gigartina stellata appeared at 303 feet $(-5.0$ feet), and from there onwards both these algæ occurred intermittently to low water mark.

Littorina obtusata was abundant on all parts of the traverse above -7.5 feet which were covered by weed-it was still common in the upper foot of the Laminarian zone. Littorina littorea was rare on this part of the reef, as were Gibbula umbilicalis, G. cineraria, Nucella lapillus and Calliostoma zizyphinum, except that the latter was fairly common about low water mark, though never so numerous as on the eastern side of the reef. Patella vulgata was abundant on bare patches of rock at all levels down to -6.5 feet.

After the cleft, at 50 feet, there were no barnacles until 309 feet, just after Mark VII on top of an otherwise bare rock, where there was a small colony of Chthamalus stellatus at $-5 \cdot 22$ feet. Verruca stromia, as on Traverse A, was always living among the holdfasts of Laminaria digitata.

Traverse C. 382 feet. From Central Rock N. towards Wembury Church. See Fig. 5 .

Unlike Traverses A and B, C is, except for the first few feet on Central Rock, between High and Low Water Neaps, and since it undulates considerably between these limits it gives a fairly complete picture of the state of affairs around Mean Sea Level.

Central Rock is not separated from the rest of the reef on the landward side as it is to seaward by the cleft, nor is it so steep. Except in pools it is also very bare of algæ, the only common plant being Lichina pygmaea. Small Patella are common on the upper portion. The traverse first of all descends in steps to the bottom of a deep pot-hole with the water level at $+1 \cdot 6$ feet. This pot-hole contains undersized plants of Laminaria digitata, but, as already mentioned during the description of Traverse B, this pool is always shaded from the sun except around noon during the summer. The barnacles at the top of Central Rock were again all Chthamalus stellatus, Balanus balanoides appearing at 4 feet from C.R. at a height of $+4 \cdot 29$ feet. The steep sides of the pot-hole are bare, but Lichina pygmaea nearly covers the rocks from C.R. to 4 feet and from 8 feet to 10 feet. Littorina saxatilis is common on this stretch. A shallow pool intervenes from 10 feet to 18 feet, and is almost filled with Bifurcaria tuberculata, after which the traverse climbs to $+3 \cdot 46$ feet at 23 feet, being covered with Lichina, Balanus balanoides, Chthamalus and Littorina saxatilis. On the subsequent downward slope Chthamalus stellatus occupies the first foot, and from +2.5 feet to the bottom at a height of +0.04 feet there 

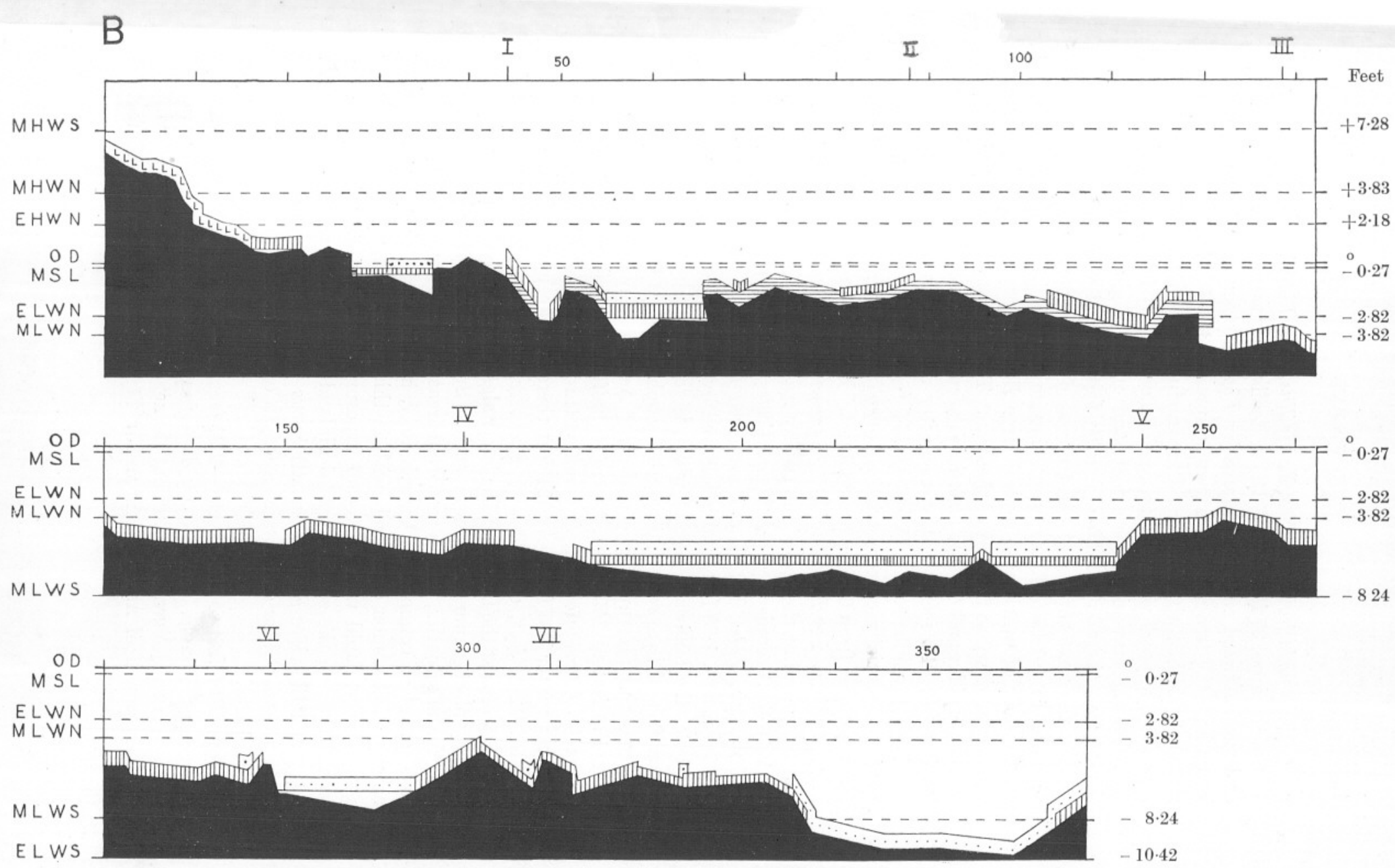

Fig. 4.-Traverse B ; distribution of Lichina pygmcea, Polysiphonia lanosa and fucoid algæ. For meaning of symbols, see Fig. 3. (Vertical scale twice the horizontal.) 
are Gibbula umbilicalis and Nucella lapillus, with Littorina littorea at the foot of the drop, 27 feet from C.R. A small pool is then crossed to 31 feet, and the landward edge is bordered by Lichina pygmaa above 0.04 feet. From here the traverse slopes gently upwards to 51.5 feet and is intermittently clothed with Lichina. Chthamalus is also present, and Littorina saxatilis reappears when the traverse reaches $+1 \cdot 4$ feet at 41 feet. At 5i.5 feet the traverse drops a foot, and on the slight rise to 60.5 feet, $+2 \cdot 17$ feet, there are Lichina, Nucella lapillus and Gibbula umbilicalis. During the next three feet the traverse descends more than the same distance, to $-1 \cdot 19$ feet, the drop being interrupted by a deep overhang on the floor of which were several large Balanus perforatus, which continued also down to the foot of the drop. The highest was at +0.88 feet. Nucella lapillus and Gibbula umbilicalis occupied the same region.

After $\mathrm{C}_{\mathrm{I}}, 64.5$ feet, the traverse, after dropping from -1.02 feet to -1.76 feet, climbs to +1.75 feet at 76.5 feet. As far as 74.5 feet $(+0.9$ feet) it is partially covered with Ascophyllum nodosum, with a patch of Fucus serratus from 66.5 feet to 68.5 feet. Barnacles, mainly Chthamalus but including a few $B$. balanoides, are present from about O.D. at 72 feet, and are joined at the top of the rise by scattered Lichina pygmaxa. The next stretch, occupied by Gibbula umbilicalis, Nucella lapillus, Chthamalus, Balanus balanoides, Patella and scattered Lichina, is nearly level as far as 96 feet at $+1 \cdot 88$ feet, and is followed by a three-foot drop into a bare pot-hole, the landward side of which is rather more than a foot high. A few feet of bare rock and sparse Ascophyllum are then succeeded by an almost uninterrupted sheet of dense Ascophyllum and Polysiphonia from 108 feet to 255.5 feet, the most uniform stretch of vegetation on the reef. Littorina obtusata is common throughout, and $L$. littorea fairly numerous after 155 feet. At 151 feet there is a steep drop from +0.48 feet to -2.04 feet, covered with Fucus serratus, and with Patella and $F$. vesiculosus at the bottom. The latter alga, though growing abundantly in many places around Plymouth, such as Sutton Harbour and the Tamar and Yealm estuaries, and on restricted areas in Wembury Bay, is nowhere widespread or common on Church Reef, and is therefore not included among the common algæ dealt with in this paper. This distribution is perhaps correlated with degree of exposure, though it should be mentioned that on the south coast of Finland (where the salinity is about $4 \%$ and the tides are very small) Fucus vesiculosus grows abundantly among the breakers and attains a length of two or three metres (Segerstråle, 1928).

From 151.5 feet to 155.5 feet $(-2.04$ feet to -1.99 feet) there are bare stones and shingle, occupied by Littorina littorea, Gibbula umbilicalis, G. cineraria and Nucella lapillus, but the next twenty feet are covered with a thick growth of Ascophyllum with a little Fucus serratus at 173 feet 


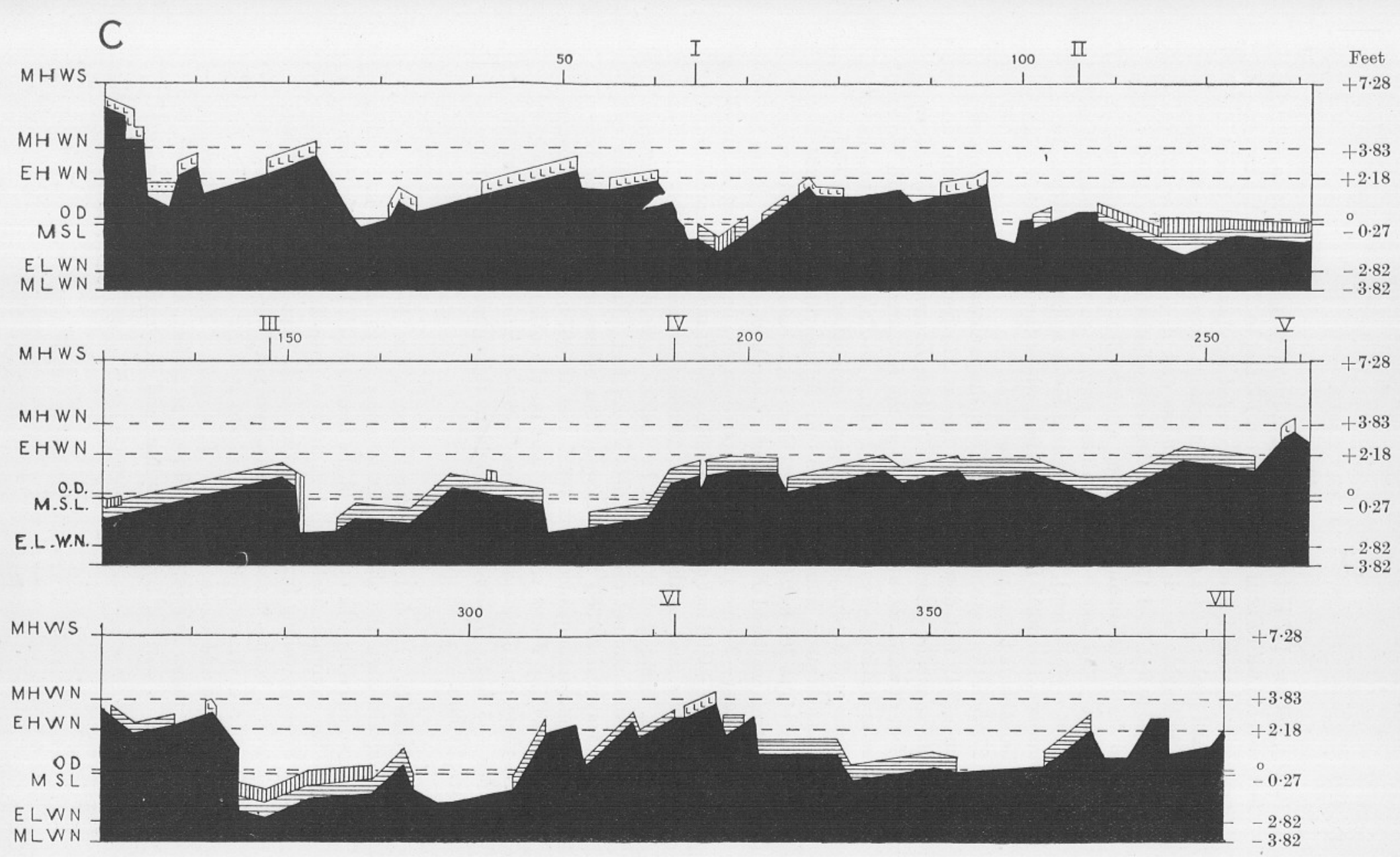

FIG. 5.-Traverse C; distribution of Lichina pygmaa, Polysiphonia lanosa and fucoid algæ. For meaning of symbols, see Fig. 3. (Vertical scale twice the horizontal.) 
(O.D.), until at 177 feet there is again a drop (from $-0 \cdot 46$ feet to $-2 \cdot 13$ feet) covered with Fucus serratus. From 185 feet to 255.5 feet the traverse gradually rises and is continuously covered by Ascophyllum except for two small pools ; Fucus serratus is also present from 212 feet to 223 feet, * attaining heights of +1.39 feet at 215 feet and of +1.40 feet at 223 feet. From 255.5 feet $(+1.43$ feet) the traverse climbs as far as 259.5 feet $(+3.51$ feet), Chthamalus appearing at +2.3 feet and being joined by Lichina at +2.9 feet. Lichina is also present on the next summit at 272.5 feet $(+3 \cdot 19$ feet), the intervening lower section supporting Ascophyllum between 262.5 feet and 268 feet, where the rock is below $+2 \cdot 49$ feet, hereabouts the upper limit of this alga.

At 272.5 feet comes another of the steep drops characteristic of Traverse C, from $+3 \cdot 19$ feet down to $-2 \cdot 25$ feet at 275 feet. Chthamalus and Balanus balanoides extend down to +2.5 feet, Laurencia pinnatifida from +1.0 feet downwards, and the rocks at the foot are covered with Fucus serratus and Ascophyllum nodosum. I found no Balanus perforatus here. $F$. serratus and Ascophyllum accompany each other as far as 289.5 feet, but the subsequent hump supports only Ascophyllum. From 294 feet $(-1 \cdot 11$ feet) to 305 feet $(-1 \cdot 15$ feet) there are stones and rocks on which are growing scattered Fucus vesiculosus (see above, p. 448). From 305 to 308.5 feet $(+2.0$ feet) there is Ascophyllum, the next few feet, followed by a drop to $+0 \cdot 08$ feet at 312.5 feet, being bare save for Chthamalus and $B$. balanoides, and on the next rise Ascophyllum reaches +2.88 feet at 322.5 feet, being then succeeded by Lichina, accompanied by Littorina saxatilis, to a summit of $+3 \cdot 61$ feet at 327 feet. From here to the end of the traverse at 382 feet, Ascophyllum occurs intermittently below +2.78 feet, accompanied from 362.5 feet to 367.5 feet $(+0.15$ feet to +2.25 feet) by Fucus vesiculosus, and on the otherwise bare rock at C vII there are Chthamalus stellatus, Littorina littorea, and L. saxatilis above +3 feet. L. obtusata is abundant throughout wherever there is Ascophyllum.

Traverse D. 198 feet. Eastwards from C vir. See Fig. 6.

This, although the shortest, is in many ways the most interesting traverse, since it is the only one of the four to reach High Water Springs, where the environmental conditions for algal growth are far more severe than those prevailing further down the shore. The rock at $\mathrm{C}$ vII where the traverse begins is capped, as has been mentioned at the end of the description of Traverse C, by Chthamalus stellatus accompanied by Littorina littorea and above +3 feet by $L$. saxatilis. The traverse descends, except for minor humps, to +0.69 feet, at 25 feet, and from 6.5 feet to 17 feet it is covered by Ascophyllum and Polysiphonia, with a little

\footnotetext{
* Not shown in Fig. 5 .
} 
Fucus vesiculosus from 6.5 feet to 10 feet at about +1.5 feet. Littorina obtusata and Gibbula umbilicalis are both common here, as is Osilinus lineatus, which was found on none of the other traverses, and is apparently confined to the north-eastern part of the reef where it is quite common within its narrow range. From 17 feet to 25 feet the floor is stony, and after storms is frequently covered a foot or so deep with torn-off algæ and various jetsam. From 25 feet $(+0.69$ feet $)$ to 51.5 feet $(+3.40)$ there is continuous growth of Ascophyllum, not very thick, with some bare rock showing. At 25 feet there is Balanus balanoides growing on the rock, and also Littorina littorea, L. obtusata, and Gibbula umbilicalis, after which the traverse climbs to +2.44 feet at 27.5 feet, where the same animals are present with the addition of Littorina saxatilis, whose lower limit on bare rock hereabouts just overlaps the upper limit of $L$. littoralis amongst Ascophyllum, which remains damp even after six hours' exposure to the sun on a hot June day. At 33 feet the traverse reaches +3.24 feet, and there is a small patch of Fucus spiralis. At 51.5 feet $(+3.40$ feet) Ascophyllum abruptly gives way to Fucus spiralis, of which there is an almost pure stand as far as 92.5 feet $(+5 \cdot 28$ feet) where it, as abruptly, is replaced by Pelvetia canaliculata, of which there was previously a patch at $81 \cdot 5$ feet $(+4 \cdot 91$ feet). At 96 feet $(+5 \cdot 2$ feet $)$, the traverse is just at the lower edge of the Pelvetia zone, and again at $105 \cdot 5$ feet $(+5 \cdot 28$ feet) on the side of a ditch, after which the traverse continues its gentle upward slope to 121 feet $(+6.93$ feet), still covered by Pelvetia and with Littorina saxatilis common. At 124 feet the level has fallen to +2.95 feet, and on this drop Pelvetia extends down to $+5 \cdot 79$ feet, Fucus spiralis from that point down to +3.85 feet, Littorina saxatilis down to +5.5 feet and $L$. obtusata up to +4.5 feet, the two gastropods failing to overlap here as they did at 27.5 feet. On the subsequent hump, Fucus spiralis extends from $+3 \cdot 5$ feet to $+5 \cdot 45$ feet with Pelvetia covering the summit which reaches $+5 \cdot 80$ feet at 129 feet, and the further side supports Fucus spiralis from +5.4 feet down to the bottom at +3.19 feet, 130.5 feet from C vII.

The traverse rises again slightly to 140 feet (Fucus spiralis) but then descends steadily to -0.08 feet at 172 feet, patches of Ascophyllum occurring below $+3 \cdot 27$ feet. Up the next steep climb to $+3 \cdot 81$ feet at 178 feet Ascophyllum reaches $+3 \cdot 17$ feet, and reappears in the next depression at 180.5 feet at a height of $+3 \cdot 2$ feet, accompanied by Patella. The traverse then rises to the end, Fucus spiralis occurring between +3.50 feet and $+5 \cdot 6$ feet, with Littorina littorea up to $+4 \cdot 3$ feet, and Pelvetia from $+5 \cdot 6$ feet up to $+7 \cdot 49$ feet. Above this is the thickest growth of Chthamalus stellatus, reaching $+9 \cdot 6$ feet hereabouts (the line of the actual traverse ended at $+8 \cdot 34$ feet). Littorina neritoides is now common for the first time, and its upper limit, surprisingly sharp, was 

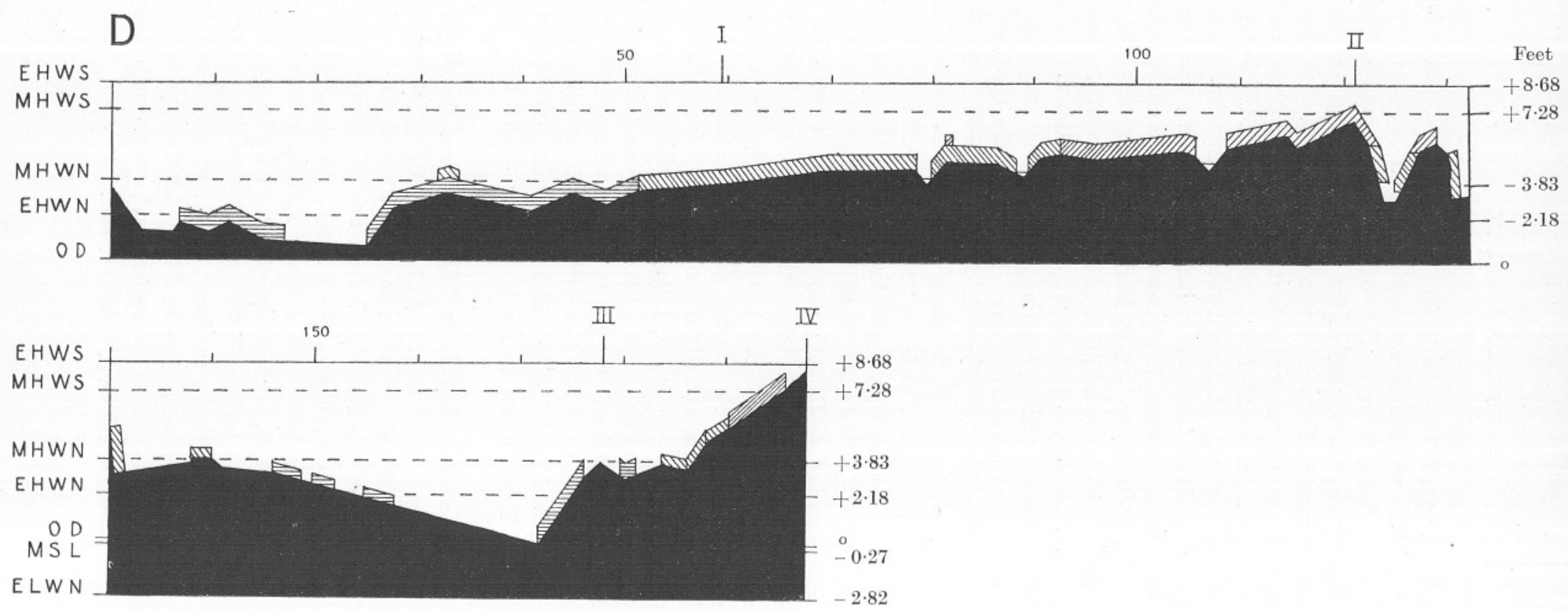

FIc. 6. - Traverse D ; distribution of Polysiphonia lanosa and fucoid algæ. For meaning of symbols, see Fig. 3. (Vertical scale twice the horizontal.) 
levelled at +14.93 feet. Its lower limit is somewhat uncertain. It was abundant down to $+9 \cdot 2$ feet, about 1.5 above Pelvetia, and seemed to stop there, but after a prolonged search two specimens were found at the bottom of the Pelvetia zone at $+5 \cdot 6$ feet. None could be found in the intermediate region. Littorina saxatilis is common to its upper limit, again quite sharp, at +14 feet, and extends without any break right through both the Pelvetia and the Fucus spiralis zones.

These descriptions of the traverses are summarised in Tables IV and V and in Figs. 3, 4, 5 and 6.

\section{Splash ZoNe.}

In an attempt to correlate tidal data with the distribution of species on the shore, it must always be borne in mind that the "splash zone" formed by the breaking waves raises the tide marks above their level predicted in the tide tables, or recorded by a tide gauge (most types of which ignore wave action). The height of the splash zone is obviously of great importance, but it is seemingly impossible to estimate with any exactness, varying as it does with the weather, with the amount of general exposure of the rocks to the surf, and with the detailed shape of the rocks. I think that two feet would be a conservative average estimate of the splash zone over a long period on Church Reef. Orton (1929) takes the same figure in considering the vertical range of Patella vulgata. During the winter, continued storms will keep the height of the splash zone at five feet or more, whereas during the summer there may be periods of several days when there is only the smallest sea running, or, rarely, none at all with a light off-shore breeze. It may be pointed out that a breaking sea will wet the splash zone almost at once, whereas it would take some minutes for even the superficial water to dry or drain off. It would therefore seem that for small animals, at any rate, and to a large extent for plants, the splash zone is almost as wet as the sea itself (since it is rewetted every few seconds) and is also at the same temperature as the sea, and that the tidal level at any time is that reached by the surf, and not that of the real sea-level at that time.

\section{Exposure Related to Level on the Shore.}

First of all the relation must be examined between the vertical level on the shore and the amount of exposure or immersion; then the positions of the upper and lower limits of species can be compared with the data so obtained.

If height on the shore is plotted against hours of exposure, one of two curves will result. When plotted for one tide a simple curve is obtained (Fig. $7 \mathrm{~A}$ and $\mathrm{B}$; Table VI, columns $a$ and $b$ ); the same is true at 
TABLE IV.

Plants: Upper (u.) and Lower (L.) Limits above ( + ) or below ( - ) Ordnance Datum, in feet. L.W.M. $=$ LOW WATER MARK.

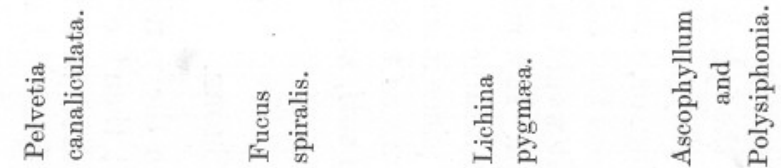

Traverse.
U. v.

$$
\begin{array}{cc}
\text { U. } & \text { L. } \\
+6.04 & +0.4 \\
& +0.4 \\
& +0.57 \\
& +0.3
\end{array}
$$

A.

B.

C.

D.

$$
\begin{array}{rlll}
+7 \cdot 49 & +4 \cdot 91 & +5 \cdot 28 & +3 \cdot 24 \\
& +5 \cdot 28 & +5 \cdot 79 & +3 \cdot 40 \\
+5 \cdot 2 & +5 \cdot 45 & +3 \cdot 85 \\
& +5 \cdot 28 & +5 \cdot 4 & +3 \cdot 5 \\
& +5 \cdot 79 & +5 \cdot 6 & +3 \cdot 19 \\
& +5 \cdot 45 & & +3 \cdot 5 \\
& +5 \cdot 6 & &
\end{array}
$$$$
\begin{gathered}
\hat{\uparrow} \\
+6.04
\end{gathered}+0.68
$$

$$
\begin{aligned}
& \text { L. } \\
& -4.05
\end{aligned}
$$$$
\begin{aligned}
& -3 \cdot 7 \\
& -4 \cdot 11
\end{aligned}
$$

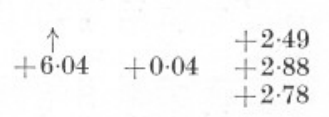

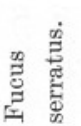

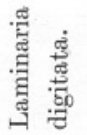

$$
\begin{gathered}
\text { L. } \\
-9 \cdot 0-
\end{gathered}
$$

U.

$-5 \cdot 55$ $\begin{array}{cc}-6.39 & \text { L.w. } \\ -6.51 & \downarrow\end{array}$ -6.50
-6.41 -6.41
-6.41$$
-6 \cdot 7
$$$$
\begin{array}{cc}
-8 \cdot 4 & -6 \cdot 23 \\
-8 \cdot 6 & -6 \cdot 54
\end{array}
$$$$
\begin{array}{cc}
-8 \cdot 4 & -6 \cdot 23 \\
-8 \cdot 6 & -6 \cdot 54 \\
& -6 \cdot 51 \\
& -7 \cdot 01
\end{array}
$$

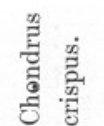

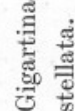

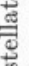

(n)




\section{TABLE V.}

Animals: Upper (U.) and Lower (L.) Limits above (+) or Below (-) Ordnance Datum, in Feet. L.W.M.=Low Water Mark.

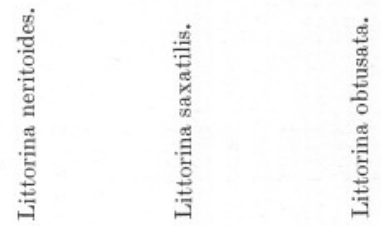

Traverse. U

A.

B.

c.

D.

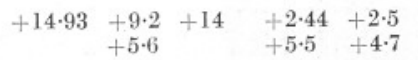

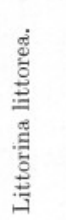

L. U, I.

$-6 \cdot 5$

$-7 \cdot 5$

$\uparrow$
$+6 \cdot 04$
$+2 \cdot 89$

$\begin{aligned} \uparrow & \\ +6 \cdot 04 & +1 \cdot 4 \\ & +3\end{aligned}$

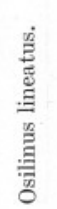

U.

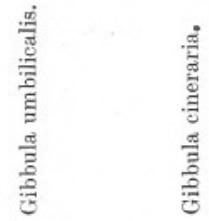

U.

L. U. I.
$-7 \cdot 0$

$-6 \cdot 5-6 \cdot 5$

$\begin{array}{lll}-8 \cdot 0 & -3 \cdot 2 & -8 \cdot 6\end{array}$

$+2 \cdot 5 \quad-2$

$+2 \cdot 17$

$+3 \cdot 4+1 \cdot 5+2 \cdot 44$

Extremes.

Means.

$$
\begin{aligned}
& +14 \cdot 93+5 \cdot 6+14+1 \cdot 4+4 \cdot 7 \quad-7 \cdot 5+4 \cdot 3 \quad-7 \cdot 0 \quad+3 \cdot 4+1 \cdot 5+2 \cdot 5 \quad-8 \cdot 0 \quad-2 \quad-8 \cdot 6 \\
& +14 \cdot 93+7 \cdot 4+14+3 \cdot 05+3 \cdot 36-7 \cdot 0 \quad+4 \cdot 3 \quad-6 \cdot 75+3 \cdot 4 \quad+1 \cdot 5 \quad+2 \cdot 37 \quad-7 \cdot 25 \quad-3 \cdot 9 \quad-8 \cdot 6
\end{aligned}
$$
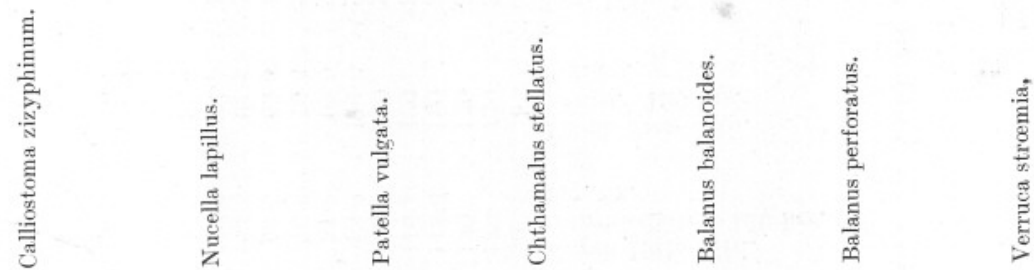

$$
\begin{aligned}
& \text { Traverse. U. L. U. L. U. L. U. L. U. I. U. } \quad \text { U. U. } \quad \text { U. } \\
& \text { A. } \quad-6 \cdot 2 \text { L.W.M. }
\end{aligned}
$$

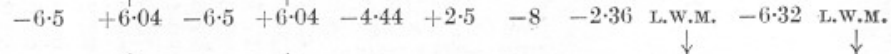

$$
\begin{aligned}
& \text { B. } \quad-7 \cdot 0 \text { L.w.M. } \\
& \begin{array}{ccccc} 
& \uparrow & & \uparrow & \\
-7 \cdot 0 & +6 \cdot 04 & -6 \cdot 5 & +6 \cdot 04 & -5 \cdot 22
\end{array} \\
& \text { C. } \\
& \begin{array}{cc}
\uparrow & \uparrow \\
+6 \cdot 04 & +6 \cdot 04
\end{array} \\
& -1.40 \text { L.W.M. }-6.23 \text { L.w.M. } \\
& +2 \cdot 5 \\
& +9 \cdot 6
\end{aligned}
$$

D.

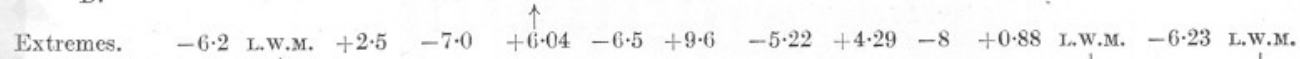

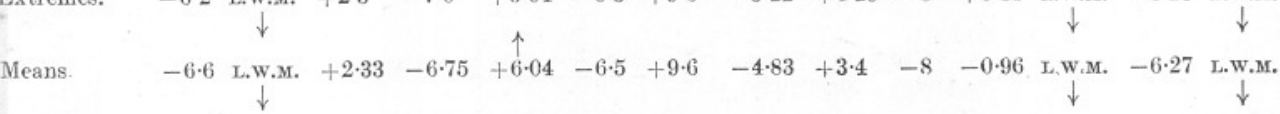


TABLE VI.

Exposure at Different Levels over various Tidal Periods; expressed in Hours, except in Column $k$ which is in Percentages.

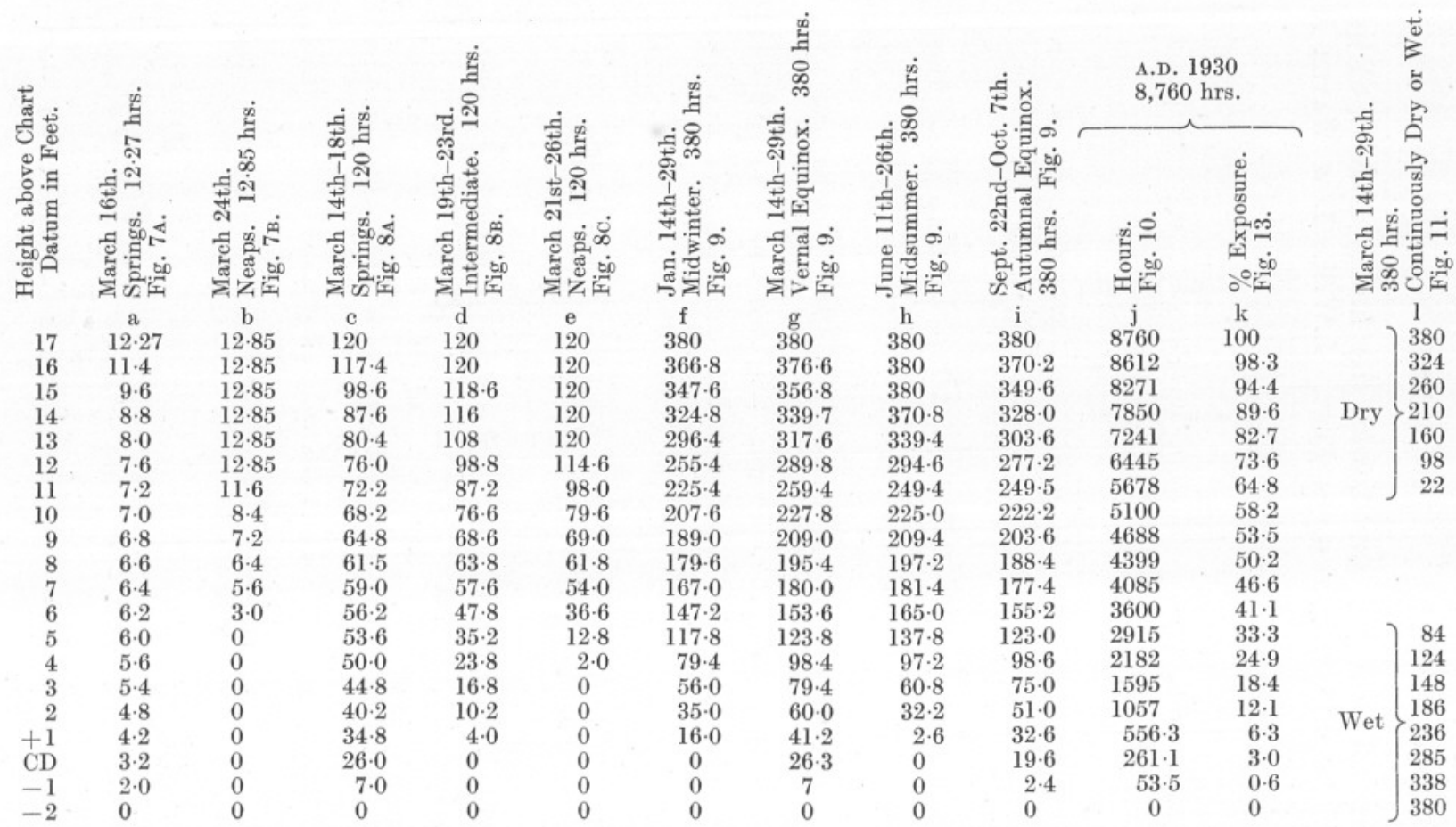


Springs over several tides taken together, as long as the amplitude of the tide is not altering (Fig. $8 \mathrm{~A}$; Table VI, col. $c$ ). Over a complete tidal

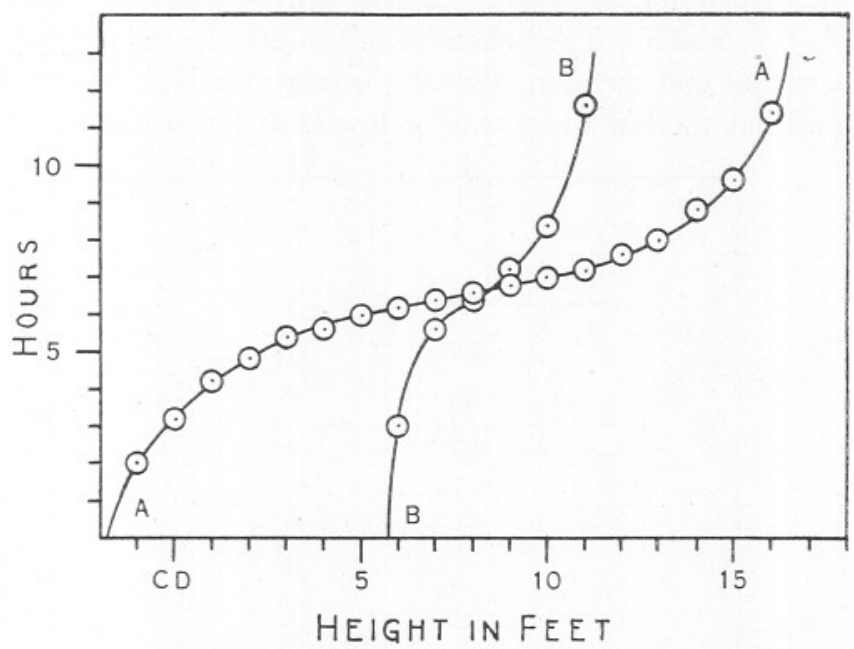

FIG. 7.-Amount of exposure at different heights during one tide. A, March 16th, 1930, springs. B, March 24th, 1930, neaps. (See Table VI, columns $a$ and $b$.)

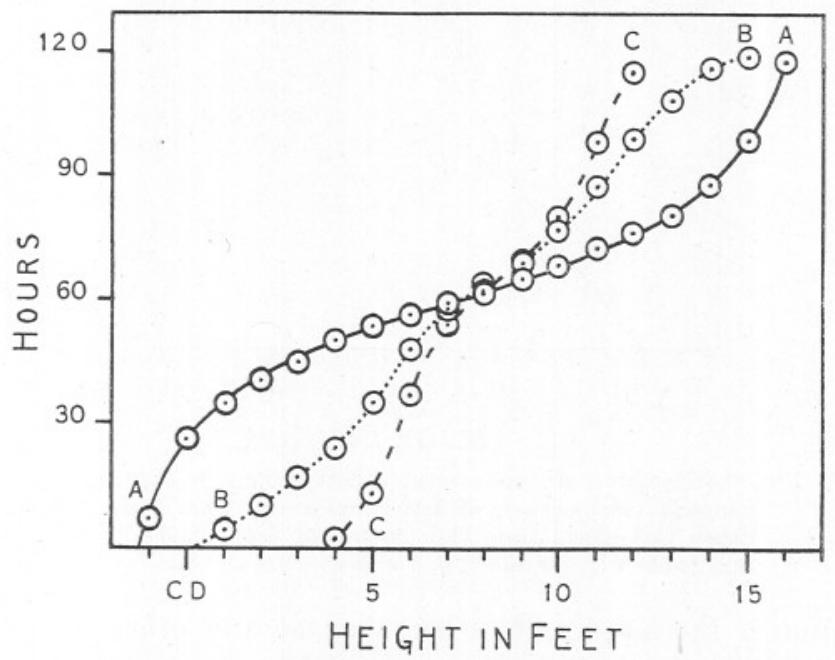

Fig. 8.-Amount of exposure at different heights during 120 hours. A, March 14th-18th, springs. B, March 19th-23rd, intermediate. C, March 21st-26th, neaps. (See Table VI, columns $c, d$ and $e$.)

period of a fortnight a more complex curve appears. In Fig. 9 the four curves represent the exposure at various heights during four fortnights 
in 1930; (1) January 14th-29th (Midwinter), (2) March 14th-29th (Vernal Equinox), (3) June 11th-26th (Midsummer), (4) September 22ndOctober 7th (Autumnal Equinox). These figures are given in Table VI, columns $f, g, h$, and $i$. They show that the equinoctial tides are very similar in spring and autumn, that the midwinter high waters are the highest of all but the low waters not so low as at the equinoxes, and that

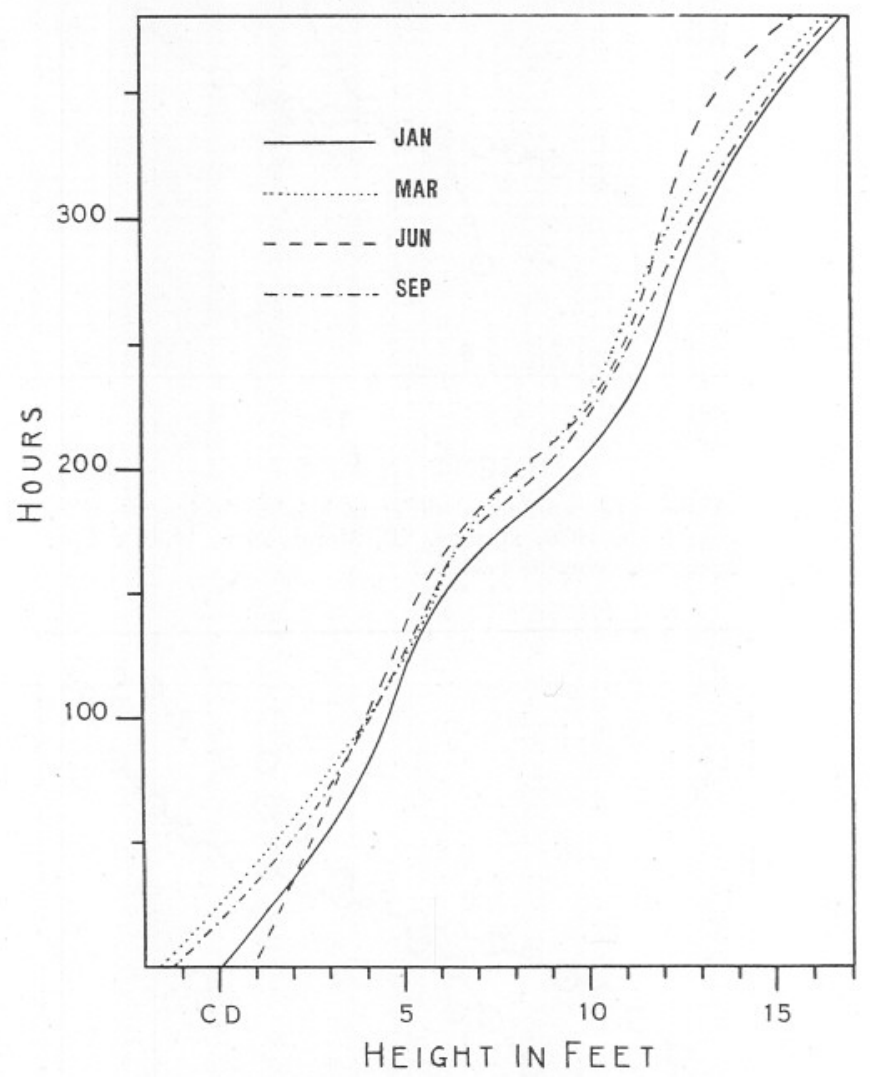

FrG. 9.-Amount of exposure at different heights during four complete tidal periods of 380 hours each: Jan. 14th-29th, March 14th-29th, June 11th-26th, and Sept. 22nd-Oct. 7 th. (See Table VI, columns $f, g, h$ and $i$.)

at midsummer the amplitude is less than at any other set of springs, high waters being lower and low waters higher.

The same compound curve is obtained over any other period, longer or shorter, as long as the tidal amplitude varies (Fig. 8 B and C ; Table VI, cols. $d$ and $e$ ).

Fig. 10 (Table VI, column $j$ ) represents approximately the exposure at different heights during the year. It is obtained by taking the sum of 
the four curves in Fig. 9 and multiplying by the requisite number of hours. The same curve is shown in Fig. 13, where the time is divided into 100 units (Table VI, col. $k$ ).

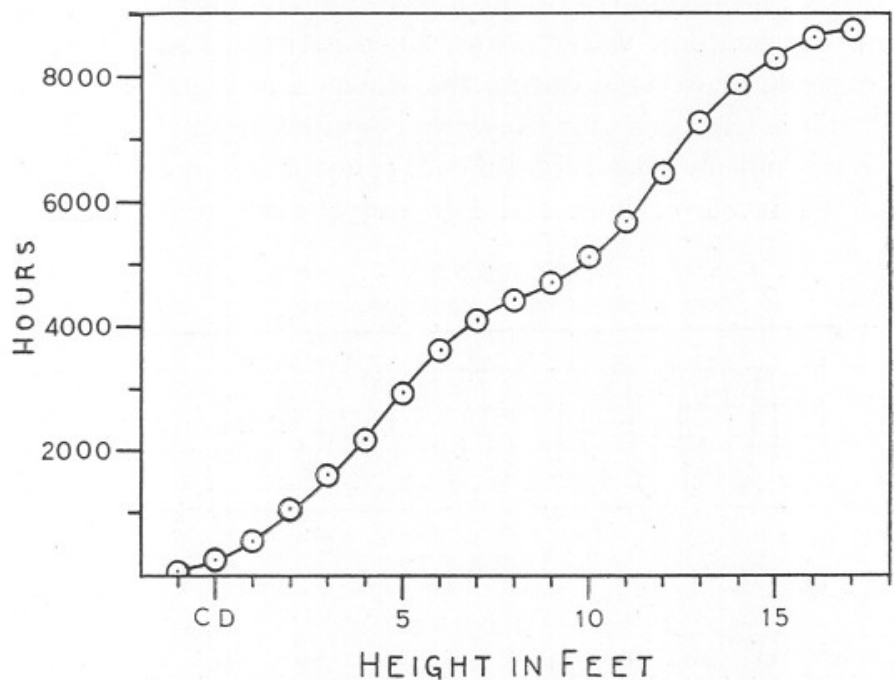

FIG. 10.-Amount of exposure at different heights during 1930. (See Table VI, column $j$.)

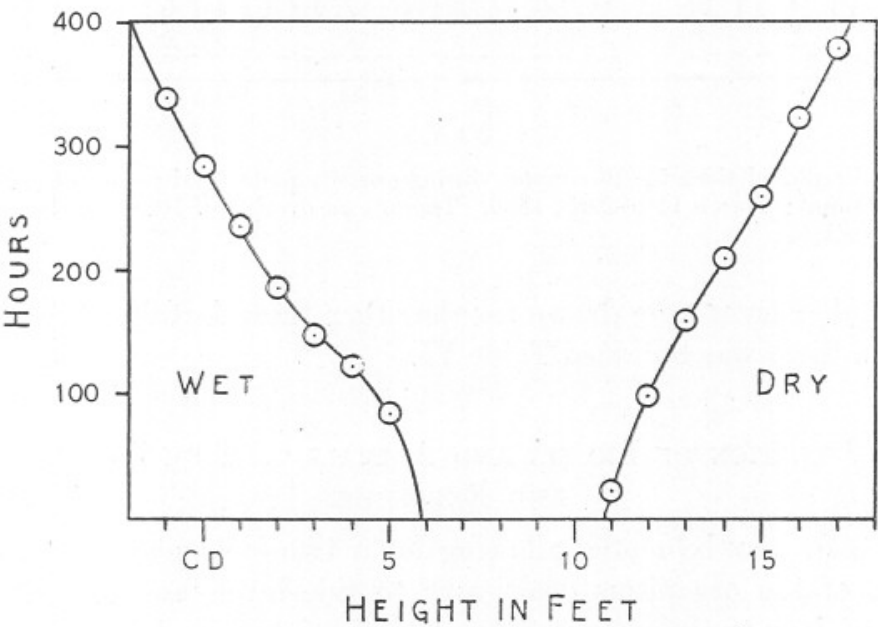

FIG. 11.-Length of time during which different levels are continuously dry or continuously wet. (See Table VI, Column $l$.)

This compound curve is built up of (1) the semidiurnal tide curve and (2) the curves, having a wave-length of a fortnight, formed by the heights of high and low waters as they vary between one set of springs and the 
next (see Fig. 12). These curves are also shown in another way in Fig. 11 (Table V, col. l), which represents the length of time during which any given level may be continuously dry or wet during one fortnight (Vernal Equinoxes). The two curves limit areas extending above extreme high and below extreme low water neaps, since between these two levels no place is exposed or covered during the whole of any one tide.

Fig. 12 shows the tides over the vernal equinox from March 14th-29th, 1930. This is not an actual tidal record ; in the absence of a tide gauge the predicted levels of high and low water were joined in free-hand.
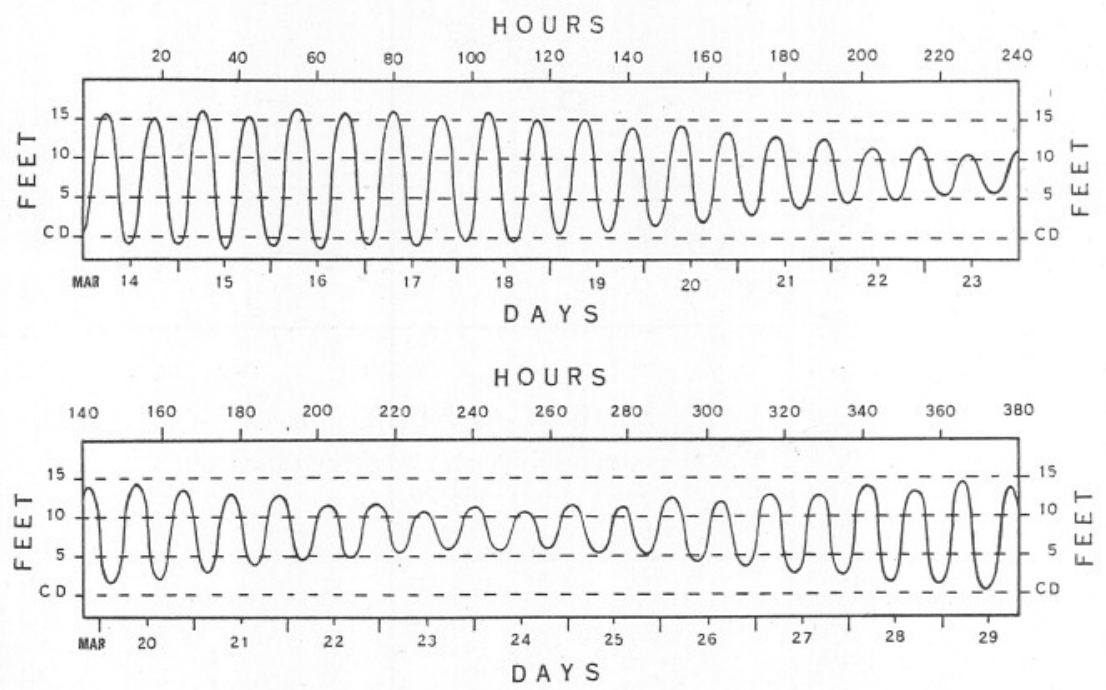

FIG. 12.- Predicted tides for Devonport during one complete tidal period of a fortnight (380 hours): March 14th-29th, 1930. There is an overlap of 100 hours between the two sections.

Similar tide curves were drawn for the other three fortnights mentioned and from them was obtained Table VI.

\section{Relation of Plants and Animals to Tide Levels and Exposure.}

A list can now be made, allowing for a two-foot splash zone, of the relations of the organisms dealt with to tide levels and to amount of exposure (given to the nearest 5\%). This list is summed up in Fig. 13.

Pelvetia canaliculata: from half-way between Mean High Water Springs and Neaps down to just above Extreme (Lowest) High Water Neaps ; from $90 \%$ to $70 \%$ Exposure.

Fucus spiralis: from Mean High Water Neaps down to a foot below Extreme (Lowest) High Water Neaps; from $80 \%$ to $60 \%$ Exposure. 
Lichina pygmaea: from above Mean High Water Neaps down to just above Extreme (Highest) Low Water Neaps; from $85 \%$ to $45 \%$ Exposure.

Ascophyllum nodosum and Polysiphonia lanosa: from just below Extreme (Lowest) High Water Neaps down to half-way between Mean Low Water Neaps and Springs; from 55\% to 15\% Exposure. From Table IV it will be seen that the upper limits on Traverse C were on an average half a foot lower than those on Traverse D. This is unexpected, since that part of Traverse D where Ascophyllum is growing is more protected than that of Traverse $\mathrm{C}$; as a rule, the greater the amount of surf the higher the upper limits of any belt, owing to the increased splash zone.

Fucus serratus : from Mean Sea Level to Extreme Low Water Springs ; from $50 \%$ to $0 \%$ Exposure.

Laminaria digitata : from Mean Low Water Springs down to below all tide marks ; from 5\% Exposure to complete immersion.

Chondrus crispus: from half-way between Mean Low Water Neaps and Springs down to below all tide marks ; from 10\% Exposure to complete immersion.

Gigartina stellata: from above Mean Low Water Springs (just below Chondrus crispus) down to below all tide marks; from $10 \%$ Exposure to complete immersion.

Littorina neritoides : from four feet above Extreme High Water Springs down to Mean High Water Springs, with two specimens at Mean High Water Neaps; from $100 \%$ to $95 \%$, with two specimens at $75 \%$ Exposure.

Littorina saxatilis : from three feet above Extreme High Water Springs down to Mean Sea Level ; from 100\% to 50\% Exposure.

Littorina obtusata: from Extreme (Lowest) High Water Neaps down to just above Extreme Low Water Springs ; from 65\% to less than 5\% Exposure.

Littorina littorea : from Extreme (Lowest) High Water Neaps down to half-way between Mean and Extreme Low Water Springs (just above L. obtusata) ; from $65 \%$ to less than $5 \%$ Exposure.

Osilinus lineatus: from just below Extreme (Lowest) High Water Neaps down to Mean Sea Level ; from $60 \%$ to $50 \%$ Exposure.

Gibbula umbilicalis: from a foot above Mean Sea Level down to just above Extreme Low Water Springs; from 55\% to less than 5\% Exposure.

Gibbula cineraria: from Mean Low Water Neaps down to Extreme Low Water Springs; from $30 \%$ to about $0 \%$ Exposure.

Calliostoma zizyphinum: from Mean Low Water Springs down to below all tide marks; from $10 \%$ Exposure to complete immersion.

Nucella lapillus : from a foot above Mean Sea Level down to half-way 


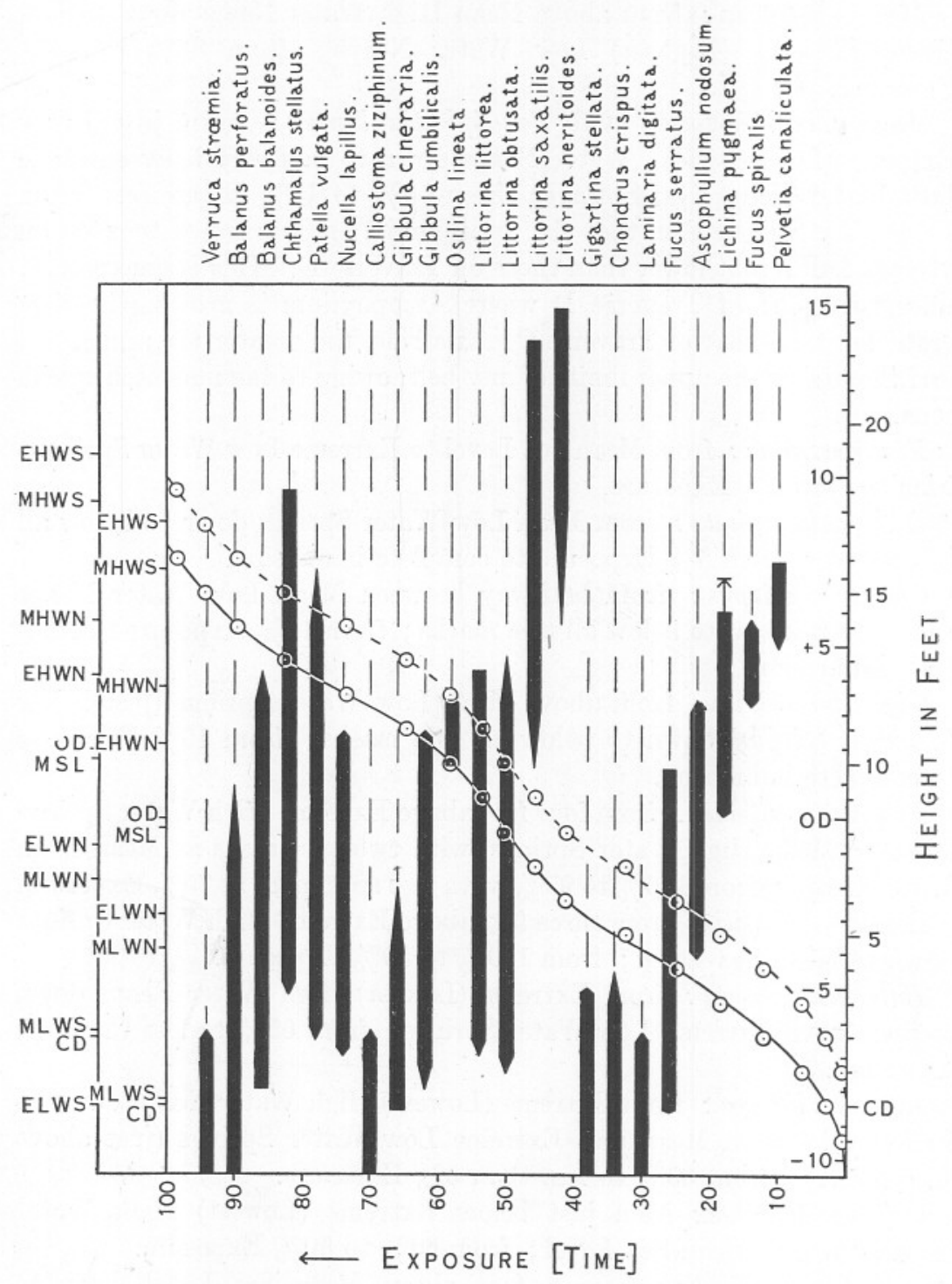

FIG. 13.-The limits of distribution of twenty-two species on the shore. Of the two columns of tide levels (EHWS to ELWS) the extreme left-hand one is two feet higher than the predicted levels, allowing for the splash zone.

The solid curve shows the percentage exposure at different heights (see Table VI, Column $k$ ). The broken curve is the same raised two feet throughout, allowing for the splash zone.

Two scales are shown on the right, in feet relative to Chart Datum and Ordnance Datum. 
between Mean and Extreme Low Water Springs; from 55\% to $10 \%$ Exposure.

Patella vulgata: from above Mean High Water Neaps down to Mean Low Water Springs; from $90 \%$ to $5 \%$ Exposure.

Chthamalus stellatus : from just above Mean High Water Springs down to above Mean Low Water Springs ; from about 100\% to $10 \%$ Exposure.

Balanus balanoides : from Extreme (Lowest) High Water Neaps down to just above Extreme Low Water Springs ; from $60 \%$ to less than $5 \%$ Exposure.

Balanus perforatus: from between Mean Sea Level and Extreme (Highest) Low Water Neaps down to below all tide marks ; from $45 \%$ Exposure to complete immersion.

Verruca strœmia: from Mean Low Water Springs down to below all tide marks; from 5\% Exposure to complete immersion.

This list is summed up in Fig. 13, which shows the vertical range of each species, and the curve formed by plotting exposure against height, as in Fig. 11 and Table VI, col. $k$.

The Relation of Levels on the Shore to the Distribution of Animals and Plants.

The ranges of intertidal species vary widely between 2 feet (Osilinus lineatus, Fucus spiralis, Pelvetia canaliculata) and 14 feet (Patella vulgata, Chthamalus stellatus), and there seems to be no a priori reason why any particular levels should be more, or less, favourable to these species, if one allows for a wide range of adaptation and specialisation among them. Nevertheless, there are certain relationships between the height on the shore and the number of species that have either their upper or their lower limits there. If the numbers of upper and of lower limits are plotted against height on the shore, two very similar curves result; each has a sharp maximum low down on the shore, a spread-out maximum higher up the shore, and an intervening minimum. These curves are smoothed curves, obtained by taking the numbers of species whose limits are between -2 and +1 feet, -1 and +2 feet, 0 and +3 feet, and so on (Table VII and Fig. 14). These heights are relative to chart datum.

For the upper limits of species, the maximum furthest down the shore is at +2 to 5 feet, the minimum at 5 to 8 feet, while the maximum at higher levels extends from 9 to 16 feet. These heights, allowing for a two-foot splash zone, correspond to between Low Water Neaps and Springs to Mean Low Water Neaps, and from Mean Sea Level to Mean High Water Springs respectively. The highest peak on the curve corresponds to Extreme (Lowest) High Water Neaps. 
In the case of the lower limits of species, the maximum furthest down the shore occurs at -1 to +2 feet, or about Extreme Low Water Springs, the minimum at 5 to 8 feet, which coincides with the minimum of upper limits at Mean Low Water Neaps, and the high-level maximum from 8 to 11 feet, or about Mean Sea Level.

\section{TABLE VII.}

Number of Species, and Limits of Species, in Relation to Tide Levels. Total Number of Species, 22.

$\begin{array}{llllll} & & & & & \\ 18\end{array}$

If a curve is made in the same way for the total numbers of species occurring at various heights, there are again two maxima and one minimum (Fig. 14). The low-level maximum coincides with that of upper limits at between Low Water Neaps and Low Water Springs; the minimum coincides with the other two minima at Mean Low Water Neaps, and the high-level maximum with that of lower limits at about Mean Sea Level.

At first sight, the relative scarcity of species at the level of Mean Low Water Neaps might seem to show that this situation was distinctly unfavourable to intertidal animals and plants. Of the species, however, that build up the maxima of the curve for Total Species, several have 
their limits just at the heights corresponding to these maxima, as shown by the other curves in Fig. 14.

If now a curve is made, plotting against height the difference in number between the total number of species and the total number of upper and lower limits, a maximum is obtained around Mean Low Water Neaps (Fig. 15). In other words, there are more species in the groups examined flourishing at Mean Low Water Neaps than at any other level on the shore; Mean Low Water Neaps is nearer the optimum of more of these intertidal species than is any other level.

The low-level maximum on the curve for lower limits shows that many

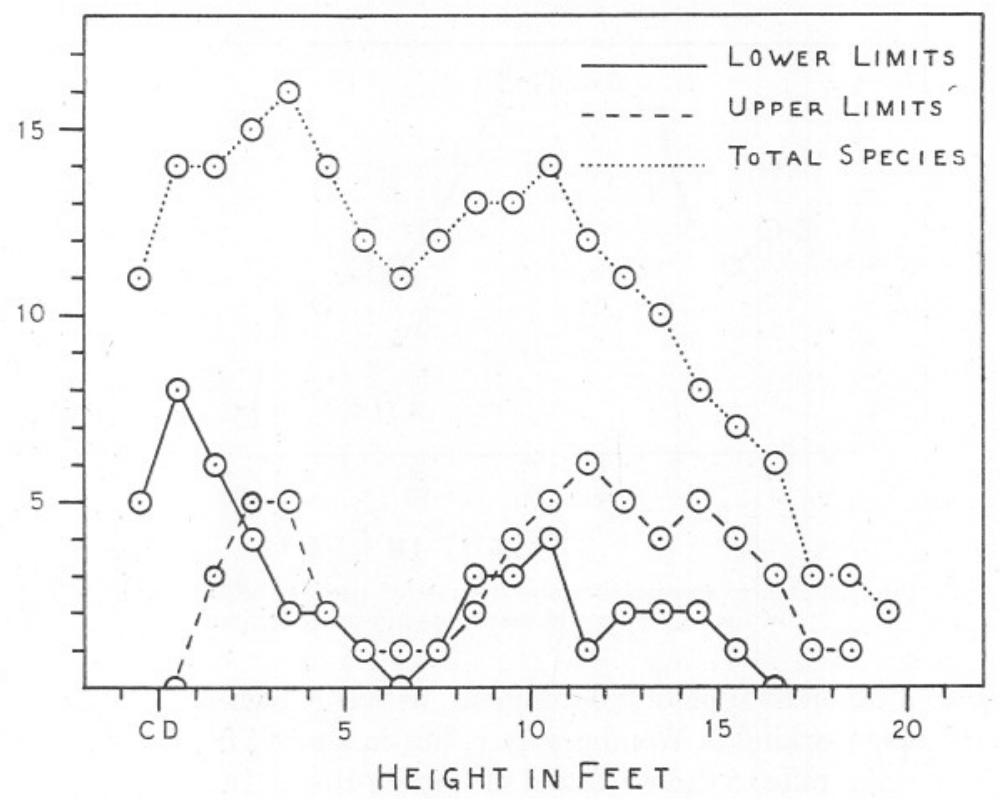

FIG. 14.-Number of species, and of upper and lower limits, at different heights.

intertidal species can live as far down as the zone between Mean and Extreme Low Water Springs, without being able to survive altogether beyond the influence of tides. Such are Fucus serratus, Littorina littorea, L. obtusata, Gibbula umbilicalis, G. cineraria, Nucella lapillus, Patella vulgata, and Balanus balanoides.

From the low-level maximum on the curve for upper limits, it appears that several species whose range is largely below the lowest tide-mark can extend nearly as high as Mean Low Water Neaps, but usually no higher. These include Laminaria digitata, Chondrus crispus, Gigartina stellata, Calliostoma zizyphinum, and Verruca strœmia. Balanus perforatus is exceptional in nearly reaching Mean Sea Level. 
The vagueness of the upper maxima in Fig. 14 seems to reflect the increasing strenuousness of the conditions for fundamentally marine creatures as high water mark is approached; in the case of the brown algæ, only by increased specialisation can they survive as they live higher, and this specialisation, of whatever nature, restricts their ranges, which decrease steadily from Fucus serratus through Ascophyllum and F. spiralis to Pelvetia canaliculata (Fig. 13).

One of the more critical levels is about Extreme (Lowest) High Water Neaps, where the upper limits of four animals on Church Reef are found, namely of Balanus balanoides, Osilinus lineatus, Littorina littorea and L. obtusata. This level, High Water Neaps, may also be very important

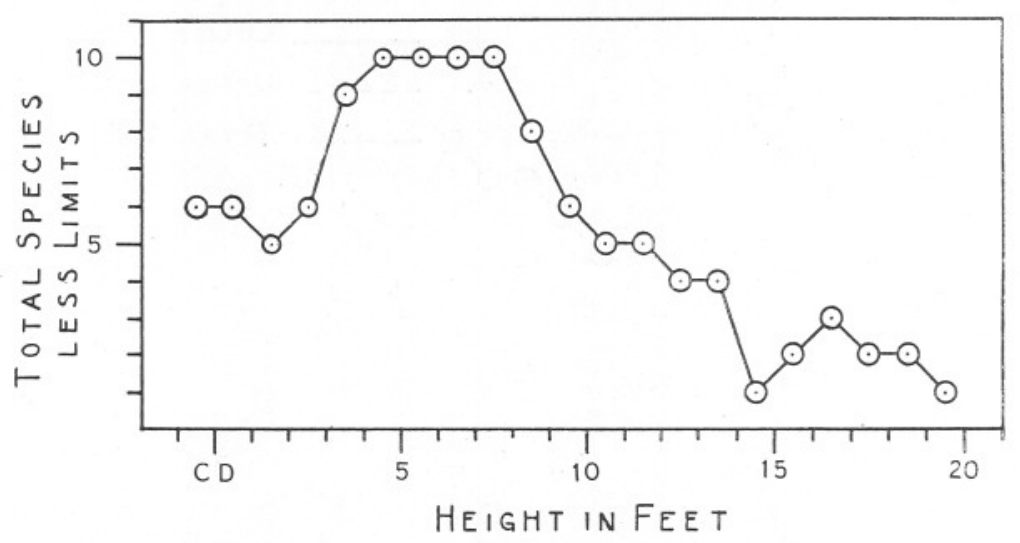

Frg. 15.-Difference between the total number of species and the total number of limits, upper and lower, at different heights.

in quite a different type of environment, as was shown by Pantin (1931). $\mathrm{He}$ was also working in Wembury Bay, but in a small fresh-water stream a quarter of a mile to the westward of Church Reef. In this stream there are large numbers of the triclad Procerodes (Gunda) ulvae and the "archiannelid" Protodrilus flavocapitatus, but Pantin found that they are confined between the levels of High and Low Water Neaps. Above High Water Neaps there is a "desert region " in this stream, until a fresh-water flora and fauna are encountered at High Water Springs. High Water Neaps, then, is a critical level in the very different environments of exposed rock and the bed of a fresh-water stream ; but whereas on Church Reef Low Water Neaps is the optimum level for many intertidal organisms, in the stream it is the lower limit for species living in somewhat peculiar estuarine conditions. This contrast emphasises the manifold ecological importance of neap tides.

There are, then, three levels on the shore on Church Reef which appear to be more critical than others, in the case of our 22 species. 
1. Between Mean and Extreme Low Water Springs; the lower limit of several intertidal species; less than $5 \%$ Exposure.

2. Between Mean Low Water Neaps and Springs; the upper limit of several submarine species; about $20 \%$ exposure.

3. Extreme High Water Neaps; the upper limit of several intertidal species; about $60 \%$ exposure.

The least critical level is Mean Low Water Neaps, with about $40 \%$ exposure.

These statements are applicable to Algæ and Barnacles considered over a long time, since they do not move about. Gastropods complicate the issue by moving, and as this survey was done largely at Springs it cannot be stated with certainty that these animals occupy the same positions at Neaps as at Springs. However, the only gastropods which are found above the level of High Water Neaps are Patella vulgata, Littorina saxatilis, and $L$. neritoides. None of the others climb above High Water Neaps during Spring tides, and during Neaps the three gastropods mentioned can be found staying still, and not reached by the tide for several days at a time. Long period data would therefore seem to be as applicable to gastropods as to the sedentary barnacles and plants, at any rate in the upper tidal region.

To my mind the most extraordinary habitats on the shore are those of Littorina saxatilis and L. neritoides. Both of them extend up the rocks several feet above High Water Mark, where for weeks during a calm summer their sole source of moisture is dew, rain if any, and perhaps the dampness caused by salt on the rocks. They congregate not only in cracks and crannies where it is damp, but also in hollows which are quite dry and bare and also directly face the sun. It is possible that this search for hollows and cracks is more an avoidance of the mechanical force of the wind than of the desiccation caused by it (teleologically speaking). This is suggested by the fact that they are always very loosely attached to the rock, so that one can easily blow them off. Fränkel (1927), who worked on the tropistic reactions of Littorina neritoides at Naples, where they live between three and eight metres above the sea, found that they are $(a)$ negatively geotropic, $(b)$ negatively phototropic when above a horizontal substratum, but $(c)$ positively phototropic when hanging from a horizontal ceiling. The resultant of these reactions would make the animals congregate round the entrances to fissures and in hollows, where, in fact, they they are found in nature. The evidence of Herdman (1890) shows that L. saxatilis, on exposed rock, may stay in the same place, apparently without moving at all, for a month or more. Finally, there is the question of their upper limits. Each is abundant as high as its upper limit and is there sharply cut off, but $L$. neritoides reaches a foot higher than $L$. saxatilis. What conditions 
in the environment can, at this height above the tides, be varying sufficiently steadily or rapidly to determine such sudden limits of these species, and at separate heights?

Another problem, at present quite unexplained, is that of the sharpness of the boundaries of certain zones, notably those of Ascophyllum-Fucus spiralis, and Fucus spiralis-Pelvetia. These boundaries vary in height slightly from place to place, but are always remarkably distinct, one alga failing to penetrate the territory of the other alga in the pair. Since each is growing thickly down or up to the boundary, this sudden stop on the part of each would appear to be due not so much to general environmental conditions as to some noxious influence on the part of one or other alga, or of both. These sharp boundaries occurred only on the upper parts of the shore.

\section{GENERAL DISCUSSION.}

The distributions described above have, of course, been well known in a rough way for many years, but previous accounts have generally been of a more general nature, and have frequently omitted any discussion of such important levels as High and Low Waters of Neap Tides. Owing to lack of uniformity in the nomenclature of different levels on the shore, it is often difficult to make any close comparison between zonation as given in accounts from different regions, and it is therefore urged that tidal levels be given, as well as full tidal data, rather than heights only, since the amplitude of the tide is of minor or even negligible importance in deciding the character of the coastal flora and fauna and their zonation. The most striking zonation I have seen is on Loggerhead Key in the Dry Tortugas, Florida, where the extreme tidal range is less than four feet.

The zonation of algæ on Church Reef appears to be very similar in general to that at Bembridge, Isle of Wight (Baker, 1909), and that of Clare Island on the west coast of Ireland (Cotton, 1912). Lichina pygmaea, however, extends at Clare Island from the Pelvetia zone to about Low Water Neaps, although the Springs rise is much the same as at Plymouth, i.e. about 16 feet. At Wembury Bay and in the Plymouth district generally Lichina pygmaa never extends lower than Mean Sea Level, some three and a half feet above Low Water Neaps (Naylor, 1930).* Otherwise the distribution of such algæ as are mentioned from all three areas is very similar on the sheltered shore of Bembridge, on the moderately protected Church Reef and on the fully exposed Clare Island Coast. These algæ include Fucus spiralis, Ascophyllum nodosum, Fucus serratus and Laminaria digitata. (Baker dealt only with brown Algæ.)

* Relative to predicted tides; the splash zone at Clare Island is almost certainly greater than on Church Reef, which makes the difference in lower limit all the more remarkable. 
On the North American Atlantic Coast the distribution of algæ on the shore has been studied at several places, notably Mt. Desert Island, Maine (Johnson and Skutch, 1928 (a) and (b)), and Cold Spring Harbour, Long Island (Johnson and York, 1915). Direct comparison of these places with Church Reef is difficult, since the authors of both papers fail to consider the importance of High and Low Water Neaps, giving all their data in feet above or below assumed Mean Low Water Mark; which can itself be interpreted either as Mean Low Water Springs or as the average of all low waters at a given place. In a rough way it can be seen that species common to the two sides of the Atlantic, e.g. Ascophyllum nodosum, Polysiphonia lanosa, Fucus vesiculosus, Fucus spiralis and Chondrus crispus have much the same distribution wherever they occur, but with one notable exception. In Cold Spring Harbour Ascophyllum is confined between about High and Low Water Neaps $(7.5$ feet to 1.5 feet above "Mean Low Water"), but on the rocky beaches of Long Island Sound, from which Cold Spring Harbour is an inlet, Ascophyllum grows down to 1.5 feet below "Mean Low Water," and perhaps even further. This would appear to be at least as low as Low Water Springs, and is interesting in view of the sharpness of the lower limit, at predicted Low Water Neaps, of Ascophyllum on Church Reef.

Two generalisations on the zonation of algæ are worth quoting. Baker, as a result of her experimental work on the brown algæ at Bembridge, concludes: "(1) The species of seaweeds growing high up on the shore have a power of resisting desiccation which is not possessed by those growing lower down, and this power decreases regularly in those species growing towards the lower levels. (2) The seaweeds which can best resist desiccation grow most slowly, and those that grow most quickly are the least tolerant of desiccation." Johnson and Skutch (1928 b) say: "The vertical range of a species is a measure of its tolerance of loss of water, toward its upper limit, and of loss of light, toward its lower limit."

With regard to the barnacles and the molluses other than the four species of Littorina, I have been able to find no accurate measurements of their upper and lower limits in other places, such work as the Clare Island Survey being too general for comparison with that on Church Reef. Huntsman (1918) mentions that Balanus balanoides extends to below Low Water Mark at Cheticamp, Nova Scotia.

In the case of Littorina, however, there are papers by Herdman (1890), Huntsman (1918), Tattersall (1920), Gowanloch and Hayes (1926), and Hayes (1929) which contain some rather conflicting information.

Herdman, at Puffin Island, Anglesey, worked on Littorina saxatilis collected from well above High Water Mark. He found that in seawater they died after thirty-six and before seventy-two hours; in fresh water they died after four to eight days; if kept dry they remained 
stationary, but alive and well, for two months at least. Specimens marked in their natural habitat above High Water Mark were observed continuously for three days and three nights, during which time they failed to move. They were still in exactly the same positions after intervals of a fortnight and of a month.

Gowanloch and Hayes (1926) worked at St. Andrews, New Brunswick, on the ecology of Littorina saxatilis $(=L$. rudis), L. littorea, and L. obtusata. The latter animal they call $L$. palliata (Say), but I have shown elsewhere that $L$. palliata and $L$. littoralis are synonymous with $L$. obtusata (L.) (Colman, 1932).

Gowanloch and Hayes give the ranges of the three molluscs as follows:

\section{Lower Limit.}

L. saxatilis. Mid Low Tide.

L. littorea. Low Low Tide.

L. obtusata. High Low Tide.
Upper Limit. Mid High Tide. Mid Mid Tide. High Mid Tide.
Optimum Level. Low Mid Tide. Low Tide. Low Mid Tide.

For purposes of comparison with the Church Reef data I venture to transcribe these as follows:

\section{Lower Limit.}

L. saxatilis. Above Low Water Springs.

L. littorea. Low Water Springs. Mean Sea Level.

\section{L. obtusata. Low Water Neaps. Below High Water} Neaps.
Optimum Level. Above Low Water Neaps.

Above Low Water Springs.

Above Low Water Neaps.

Littorina saxatilis and $L$. obtusata are indigenous, but $L$. littorea was not introduced into Nova Scotia from Europe until shortly before 1857, but it is now abundant on the shores of New England and the Maritime Provinces of Canada (Gray, 1879; Sumner, Osburn and Cole, 1913).

It will be seen from the foregoing tables that at St. Andrews, New Brunswick, $L$. littorea and $L$. obtusata occupy very similar positions to those in which they are found on Church Reef. L. saxatilis, however, lives in a very different zone: above Low Water Springs up to below High Water Springs, instead of from Extreme (Lowest) High Water Neaps to more than five feet above Extreme High Water Springs (predicted levels). I have, however, seen $L$. saxatilis above the reach of the tide at Little Nahant, Massachusetts.

Huntsman (1918), like Gowanloch and Hayes, describes L. littorea as extending downwards no further than Low Water Springs, at St. Andrews, but he says that at Cheticamp, Nova Scotia, on the St. Lawrence side of Cape Breton Island, this gastropod can be dredged from all depths down to twenty fathoms. 
Around Woods Hole, Mass., Littorina littorea shells have been dredged from numerous positions (Sumner, Osburn and Cole, 1913), to which they had in many cases been carried by hermit-crabs. In two places living specimens were caught by the dredge, but it is probable that they had got away from the intertidal region by accident. One of these two stations was at the mouth of Hadley Harbour. Near here the tide runs each way at any speed up to five knots, and there are numbers of isolated rocks supporting many $L$. littorea and exposed to the full force of the stream. It is therefore not surprising to find numbers of this mollusc on the surrounding sea-floor, where they may have sunk after being torn away from alga or rock. The other station is towards the head of Buzzards' Bay, where masses of eel-grass are commonly floating. These masses as a rule carry Littorina littorea along with them, and when the eel-grass dies and disrupts, the mollusc must fall to the bottom where it may be dredged. It should be mentioned that $L$. littorea, though an intertidal animal, can withstand complete immersion for more than fifty days (Hayes, 1929).

The experimental work of Gowanloch and Hayes (1926) and Hayes (1929) may be summarised here, since their results are of importance in connection with upkeep of intertidal zonations.

If Littorinæ are collected from various levels on the shore, those collected higher up show :

(a) Greater negative geotropism.

(b) Greater, and commoner, positive phototropism.

(c) Less, and rarer, negative phototropism. (Some individuals show positive phototropism, some negative, and some neither.)

Prolonged desiccation leads to a marked decrease in negative geotropism, while prolonged immersion induces increased negative geotropism. The combined effect of these reactions is to make it difficult for each species to get away from its normal habitat, and in fact it was found that if $L$. littorea are moved from one place to another within the range of the species, they tend to migrate back to the level from which they were taken.

Finally, Tattersall (1920) has briefly described the zonation of Littorince in the south-west of Ireland, where the four species are distributed most densely at the following levels: L. littorea among Laminaria and Fucus serratus ; L. obtusata among Fucus vesiculosus and Ascophyllum nodosum ; L. saxatilis among Pelvetia canaliculata and Fucus platycarpus $(?=$ spiralis); L. neritoides between High Water Springs and High Water Neaps. From this scheme Church Reef differs in that the zones of $L$. littorea and $L$. obtusata are indistinguishable so far as vertical distribution is concerned, and that not only are the richest zones of $L$. saxatilis and $L$. neritoides concurrent over much of their extent, but they both reach some 
distance above Extreme High Water Mark. It appears to me that until numerous accurate determinations of levels of zones are made, with analysis of local factors such as time of day of low water springs and amount of insolation, each locality must be treated on its merits. Nevertheless, the state of affairs in South-western Ireland as described by Tattersall has been taken as generally applicable for British waters by text-books such as The Biology of the Sea Shore, Flattely and Walton (1922), and Animal Ecology, Pearse (1926). A further difference between these two localities appears to concern the hatching of $L$. obtusata, which lays its egg masses on fucoid seaweeds. Tattersall found that they hatched as late veligers, when reared in the laboratory, and had a short planktonic phase. I kept several egg masses in finger-bowls (i.e. out of a tidal environment) and the velum was always absorbed two or three days before hatching; several individuals were watched while emerging, and in every case they crawled out and never swam. All that can be said from these observations is that under roughly similar laboratory conditions there was a distinct and important difference in the hatching stages of L. obtusata from South-western Ireland and from Church Reef.

Two separate problems are presented by the zonation of barnacles and algæ on the one hand, and by that of free-living animals such as gastropods on the other.

In the first case, spores of algæ and larvæ of barnacles are free in the sea, and are apparently away from any influence that could affect their subsequent zonation when settled between tide marks.

The assumption is made, then, that the larvæ and spores, given a suitable substratum, settle in a manner entirely at random in respect of tide levels. The further assumption is made that a barnacle or an alga, once settled, never moves again. Before settling finally, however, the Cypris-like larva of a barnacle can crawl with its antennæ; Darwin (1851, p. 15) considers this only a minor function, and it is certainly not the only method of locomotion as is creeping among newly settled Gastropod larvæ. That the settling of a barnacle larva must in some cases be practically instantaneous, and final, and not a matter of "deliberation" or " choice," is shown by those individuals of Chthamalus stellatus which are found above the predicted level of Extreme High Water Springs. These barnacles can only have settled in rough weather, when the seas were raising the splash zone. Firm settling must have taken place in an interval of time not longer than that between one wave and the next, or else the larvæ would have been washed off again. A further consideration arising out of the fact that larvæ can settle in rough weather is that during such weather the water is so powerfully stirred that larvæ outside the breaker zone must settle wherever and whenever they are thrown against their substratum, their powers of swimming being quite unable to cope 
with strong water currents. When away from violent water movements, however, barnacle larvæ may be very deliberate about settling, as described by Visscher (1928, 1928a). He observed the settling of Balanus improvisus and Balanus amphitrite and found that the cyprid larvæ spent some time exploring the substratum after first alighting on it, taking sometimes as long as an hour and crawling as far as $12 \mathrm{~mm}$. before finally settling and metamorphosing.

Zonation in the algæ and barnacles, then, is the result of a hit-or-miss method. If a spore or larva settles within the environment which will suit it as an adult, it may survive. If it settles outside this range, it will sooner or later die without maturing.

In the case of the Gastropods, the adults have considerable crawling powers, and Gowanloch and Hayes (1926) have shown that under the influence of tropisms they may use these powers to remain in, or regain, their accustomed level on the shore, thus preserving their orderly zonation between tide marks.

When the larvæ are considered, however, some complications arise. Let us take the case of the Littorinæ. L. saxatilis and $L$. neritoides are both viviparous, and the young are born in the zone which they are to inhabit, and from birth they are perhaps influenced by the same tropisms as their parents; circumstantial evidence for this suggestion lies in the fact that all sizes of $L$. saxatilis and $L$. neritoides can be found together, the same being true of $L$. obtusata. The latter is oviparous, but at Plymouth the young emerge in the crawling stage (the eggs having been laid on seaweeds in the L. obtusata zone) and therefore come under the same category as those of $L$. saxatilis and $L$. neritoides.

L. littorea, however, lays eggs which are planktonic, and hatch out as planktonic larvæ. The distribution of these when settling is therefore in all probability as much a matter of chance as with the larvæ of barnacles or the spores of algæ. The settled $L$. littorea, however, do not remain fixed-they merely exchange swimming for crawling as a method of locomotion. There is, then, a possibility that even after settling the larvæ have some time to wander about in search of a suitable environment, guided perhaps by tropisms, before being killed by adverse circumstances, the inevitable fate of a barnacle larva settling in the wrong place.

To sum up, a barnacle larva or an algal spore, when it settles, is fixed for good, and its position is a matter of chance. If it is within the range of the rest of its species, it may survive. If not, it will die. An adult gastropod, though able to move, is nevertheless forced by tropisms to remain within its normal range. The young of viviparous species are born in the same zone as their parents, and perhaps come under the same tropistic influences from birth. Some gastropods have planktonic larvæ, and these settle on the hit-or-miss method. When they settle they do not 
fix themselves, and may, perhaps, even if they miss their right zone, gain it by crawling instead of dying in the wrong one.

It is hoped that this paper may help to analyse the nature and maintenance of intertidal zones. Still almost untouched, however, lies the far more fundamental problem of the origin and evolution of such zones, and it should be again emphasized that only the largest and commonest plants and animals are dealt with, and that any conclusions reached are applicable with certainty only to them.

I am grateful for the advice and encouragement of Dr. E. J. Allen while the field work was being done, and during the writing of the paper to Professor Parker and Professor Bigelow of Harvard University.

\section{SUMMARY.}

1. Church Reef, in Wembury Bay, near Plymouth, was selected for a survey of common intertidal plants and animals.

2. Four traverses were accurately levelled relative to Ordnance Datum, and their floras and faunas examined.

3. The relation between predicted tide levels and probable actual levels is discussed, and the importance of the "splash zone " is stressed.

4. As an outcome of 2 and 3, it appears that on Church Reef the most critical levels on the shore, for the species examined, are: $(a)$ between Mean and Extreme Low Water Springs; $(b)$ between Mean Low Water Neaps and Springs; $(c)$ at Extreme (Lowest) High Water Neaps. The least critical level is Mean Low Water Neaps.

5. Two special problems are presented by the upper limits of Littorina saxatitis and $L$. neritoides, and by the frontiers between Ascophyllum and Fucus spiralis and between $F$. spiralis and Pelvetia, where the algæ do not overlap.

6. The work of previous authors is discussed for comparison with the present paper.

7. An important difference is suggested between the nature of the zonation of sedentary animals and plants on the one hand, and that of animals capable of locomotion on the other hand. 


\section{REFERENCES.}

Admiralty Tide Tables. 1929. Part I, Tables for 1930. H.M. Stationery Office, London.

Baker, Sarah M. 1909. On the causes of the Zoning of Brown Seaweeds on the Seashore. New Phytologist. 8, pp. 196-202.

Batters, E. A. L. 1902. A Catalogue of the British Marine Algæ. . . . Journ. of Bot. Supplement.

Colman, John. 1932. A Statistical Test of the Species Concept in Littorina. Biological Bulletin, 62, p. 3.

Cotton, A. D. 1912. Clare Island Survey. Marine Algæ. Proc. R. Irish Acad., 31, 1, Part 15, pp. 1-178.

Darwin, Charles. 1851. A Monograph of the Sub-Class Cirripedia. Vol. I. Ray Society.

Dautzenburg, Ph., et H. Fischer. 1912. Mollusques provenant des campagnes de L'Hirondelle et de la Princesse Alice dans les Mers du Nord. Res. Camp. Sci. Monaco, 37, pp. 187-201.

Fränkel, Gottlieb. 1927. Beiträge zur Geotaxis und Phototoxis von Littorina. Zeits. f. vergl. Phys. 5, pp. 585-597.

Gowanloch, J. Nelson, and F. Ronald Hayes. 1926. Contributions to the Study of Marine Gastropods. I. The Physical Factors, Behaviour and Intertidal Life of Littorina. Contrib. to Canad. Biol. and Fisheries, N.S. 3, 4, pp. 133-166.

Gray, Arthur F. 1879.' Littorina litorea Linn., on the American Coast. Science News, April 15th, 1879.

Hayes, F. Ronald. 1929. Contributions to the Study of Marine Gastropods. III. Development, Growth, and Behaviour of Littorina. Contrib. to Canad. Biol. and Fisheries, N.S. 4, p. 26.

Herdman, W. A. 1890. Third Annual Report of the Liverpool Marine Biological Station on Puffin Island. Proc. and Trans. of Liv. Biol. Soc., 4.

Huntsman, A. G. 1918. The Vertical Distribution of Certain Intertidal Animals. Trans. Roy. Soc. Canada, Ser. 3, 12.

Johnson, Charles W. 1915. Fauna of New England. 13. List of the Mollusca. Occ. Pap. Boston Soc. Nat. Hist., p. $\%$.

Johnson, Duncan S. and Alexander F. Skutch. 1928 (a). Littoral Vegetation on a Headland of Mt. Desert Island, Maine. I. Submersible or strictly littoral vegetation. Ecology, 9, 2, pp. 188-215. 
Johnson, Duncan S. and Alexander F. Skutch. 1928 (b). Littoral Vegetation on a Headland of Mt. Desert Island, Maine. II. Tide Pools and the Environment and Classification of Submersible Plant Communities. Ecology, 9, 3, pp. 307-338.

Johnson, Duncan S. and Harlan H. York. 1915. The Relation of Plants to Tide Levels. Carnegie Inst. Publ., 206, Washington, D.C.

Marine Biological Association. 1931. Plymouth Marine Fauna. Plymouth, England.

Naylor, GLadys L. 1930. Note on the Distribution of Lichina confinis and L. pygmcea in the Plymouth District. Journ. Mar. Biol. Assoc., N.S., 16, 3, pp. 909-918.

Orton, J. H. 1929. Observations on Patella vulgata. Part III. Habitat and Habits. Journ. Mar. Biol. Assoc., N.S., 16, 1.

Pantin, C. F. A. 1931. The Adaptation of Gunda ulvoe to Salinity. I. The Environment. Journ. Exp. Biol., 8, 1.

Segerstråle, Sven G. 1928. Quantitative Studien über den Tierbestand der Fucus-Vegetation in den Schären von Pellinge (an der Südküste Finnlands). Soc. Sci. Fennica (Finska Vetenskaps-Soc.). Commentat. Biol., 3, p. 2.

Sumner, Francis B., Raymond C. Osburn and Leon J. Cole. 1913. A Biological Survey of the Waters of Woods Hole and Vicinity. Bull. Bur. Fisheries, 31, Washington.

Tandy, Geofrrey. 1931. Notes on Phycological Nomenclature, I. Journal of Botany, 69, p. 225, Sept. 1931, London.

Visscher, J. Paul. 1928. Reactions of the Cyprid Larvæ of Barnacles at the time of Attachment. Biol. Bull. 54, pp. 327-335.

Visscher, J. Paul. 1928a. Nature and Extent of Fouling of Ships' Bottoms. Bull. Bur. Fish. 43, 2 (1927). 